\title{
Maternal health commodity landscaping exercise: A snapshot of the Bangladesh program
}

\author{
Sharif M.I. Hossain \\ Population Council \\ Saumya RamaRao \\ Population Council \\ Ismat Ara Hena \\ Population Council \\ Ubaidur Rob \\ Population Council
}

Follow this and additional works at: https://knowledgecommons.popcouncil.org/departments_sbsr-rh

Part of the Demography, Population, and Ecology Commons, Family, Life Course, and Society Commons, International Public Health Commons, Maternal and Child Health Commons, and the Women's Health Commons How does access to this work benefit you? Let us know!

\section{Recommended Citation}

Hossain, Sharif M.I., Saumya RamaRao, Ismat Ara Hena, and Ubaidur Rob. 2014. "Maternal health commodity landscaping exercise: A snapshot of the Bangladesh program," Final report. Dhaka: Population Council. 

LANDSCAPING EXERCISE: A SNAPSHOT OF THE BANGLADESH PROGRAM

Sharif Mohammed Ismail Hossain Saumya RamaRao Ismat Ara Hena Ubaidur Rob COUNCIL 


\section{P. pouverion \\ Ideas. Evidence. Impact.}

Population Council confronts critical health and development issues-from stopping the spread of HIV to improving reproductive health and ensuring that young people lead full and productive lives. Through biomedical, social science, and public health research in 50 countries, we work with our partners to deliver solutions that lead to more effective policies, programs, and technologies that improve lives around the world. Established in 1952 and headquartered in New York, the Council is a nongovernmental, nonprofit organization governed by an international board of trustees.

Population Council Bangladesh

House 15B, Road 13

Gulshan, Dhaka

Bangladesh

1212

Tel: +88028821227

Fax: +88028823127

email: info.bangladesh@popcouncil.org

popcouncil.org

Suggested citation: Hossain, S.M.I., S. RamaRao, I.A. Hena and U. Rob. 2014. "Maternal Health Commodity Landscaping Exercise: A Snapshot of the Bangladesh Program." Dhaka: Population Council. 


\section{Table of Contents}

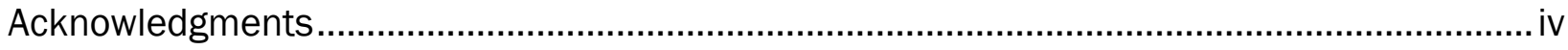

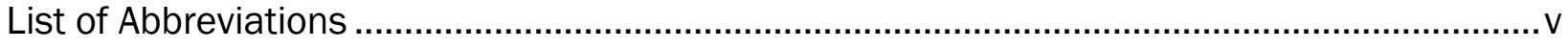

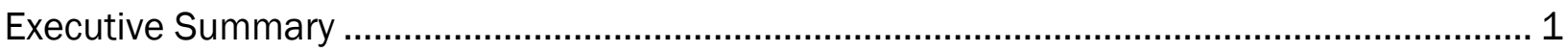

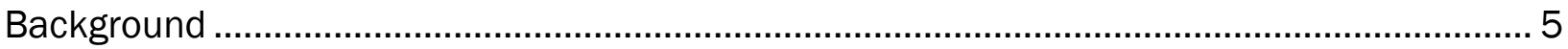

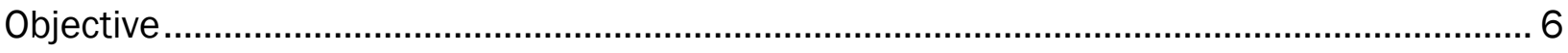

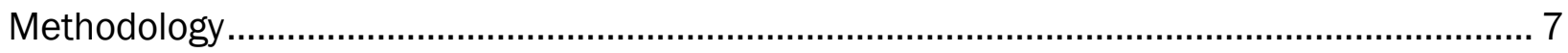

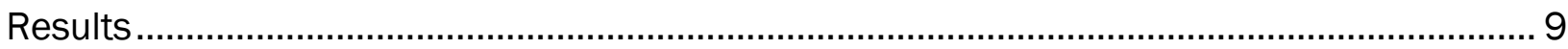

Challenges, Opportunities, Recommendations .............................................................. 19 


\section{Acknowledgments}

Population Council expresses its sincere gratitude to the William and Flora Hewlett Foundation for their interest in and financial support for this national Maternal Health Commodity Landscaping Exercise in Bangladesh.

Population Council is grateful to Dr. Mohammad Sharif, Director of Maternal and Child Health Services and Line Director of Maternal, Child and Reproductive Health of the Directorate General of Family Planning, Mr. Selim Barami, Director of Drug Administration, Ms. Rina Parveen, Director of Planning for the Directorate General of Family Planning, Dr. Md. Altaf Hossain, Program Manager for Neonatal Health of the Directorate General of Health Services, and Dr. Tapash Ranjan Das, Deputy Director of the Directorate General of Family Planning's Maternal and Child Health Unit, for their presence and active participation in a national workshop and for their valuable contributions throughout the exercise.

The Council also expresses its sincere thanks to Professor Latifa Shamsuddin, President of the Obstetrics and Gynecological Society of Bangladesh, and Professor Perveen Fatema, General Secretary of the Obstetrics and Gynecological Society of Bangladesh, for their active participation in the workshop. Being active advocates for improving maternal and perinatal health, both of them contributed singificantly to the workshop and provided policy and service delivery guidelines for the future.

We express our sincere gratitude to Mr. Toslim Uddin Khan, General Program Manager of Social Marketing Company, and Mr. Mohammad Golam Kibria, Senior Technical Advisor for Quantification and Monitoring and

Information Systems of Systems for Improved Access to Pharmaceuticals and Services, for their informative and thoughtful presentation in the workshop.

We would like to thank the respondents who participated in interviews and provided information, as well as the warehouse staff who permitted us to visit the warehouse and review stocks of the thirteen life-saving commodities. 


\section{List of Abbreviations}

\begin{tabular}{|c|c|}
\hline ANCS & Antenatal Corticosteroids \\
\hline API & Active Pharmaceutical Ingredient \\
\hline $\mathrm{BP}$ & British Pharmacopoeia \\
\hline BRAC & Bangladesh Rural Advancement Committee \\
\hline $\mathrm{CC}$ & Community Clinic \\
\hline cGMP & Current Good Manufacturing Practice \\
\hline CSBA & Community Skilled Birth Attendant \\
\hline DD-FP & Deputy Director, Family Planning \\
\hline DDS & Dietary and Drug Supply \\
\hline DGDA & Directorate General of Drug Administration \\
\hline DGFP & Directorate General of Family Planning \\
\hline DGHS & Directorate General of Health Services \\
\hline ECP & Emergency Contraceptive Pill \\
\hline EDL & Essential Drug List \\
\hline EPh & European Pharmacopeia \\
\hline EWEC & Every Woman, Every Child \\
\hline FIGO & Federation of International Gynecologist and Obstetrician \\
\hline $\mathrm{FP}$ & Family Planning \\
\hline FWA & Family Welfare Assistant \\
\hline FWV & Family Welfare Visitor \\
\hline ICDDR,B & International Centre for Diarrhoeal Disease Research, Bangladesh \\
\hline IM & Intramuscular \\
\hline IP & International Pharmacopeia \\
\hline iu & International Unit \\
\hline IV & Intravenous \\
\hline $\mathrm{kg}$ & Kilogram \\
\hline $\operatorname{mcg}$ & Microgram \\
\hline $\mathrm{MCH}$ & Mother and Child Health \\
\hline MCHIP & Maternal and Child Health Integrated Program \\
\hline MCWC & Mother and Child Welfare Center \\
\hline mg & Milligram \\
\hline $\mathrm{MgSO}_{4}$ & Magnesium Sulphate \\
\hline $\mathrm{MH}$ & Maternal Health \\
\hline $\mathrm{ml}$ & Milliliter \\
\hline $\mathrm{MNCH}$ & Maternal, Neonatal and Child Health \\
\hline
\end{tabular}




$\begin{array}{ll}\text { MNH } & \text { Maternal and Neonatal Health } \\ \text { MoH\&FW } & \text { Ministry of Health and Family Welfare } \\ \text { NGO } & \text { Non-Government Organization } \\ \text { NIH } & \text { National Institute of Health (United States) } \\ \text { NTC } & \text { National Technical Committee } \\ \text { OGSB } & \text { Obstetrics and Gynecological Society of Bangladesh } \\ \text { ORS } & \text { Oral Rehydration Salts } \\ \text { PPH } & \text { Postpartum Hemorrhage } \\ \text { PPHP } & \text { Postpartum Hemorrhage Prevention } \\ \text { PTRDS } & \text { Pre-term Respiratory Distress Syndrome } \\ \text { SACMO } & \text { Sub-assistant Community Medical Officer } \\ \text { SDG } & \text { Service Delivery Guideline } \\ \text { SIAPS } & \text { Systems for Improved Access to Pharmaceuticals and Services } \\ \text { SMC } & \text { Social Marketing Company } \\ \text { TK. } & \text { Taka } \\ \text { UH\&FWC } & \text { Union Health and Family Welfare Center } \\ \text { UHC } & \text { Upazila Health Complex } \\ \text { UN } & \text { United Nations } \\ \text { UNCoLSC } & \text { UN Commission on Life-Saving Commodities } \\ \text { UNFPA } & \text { United Nations Population Fund } \\ \text { UNICEF } & \text { United Nations Children's Fund } \\ \text { USAID } & \text { United States Agency for International Development } \\ \text { USP } & \text { United States Pharmacopoeia } \\ \text { WB } & \text { World Bank } \\ \text { WHO } & \text { World Health Organization } \\ & \end{array}$




\section{Executive Summary}

Despite consistent efforts of the government and national stakeholders, every year in Bangladesh over 5,000 mothers and thousands of children die. Most of these deaths are preventable and could be treated by increased access to quality services including existing medicines and other health commodities. The United Nation's Commission on Life-Saving Commodities for Women and Children suggests that an important cause of these deaths is lack of access and appropriate use of 13 life-saving commodities.

This document describes an effort by Population Council to assess the country's policies, guidelines, and availability for these 13 life-saving commodities as well as engaging with key stakeholders to implement the UN Commission's recommendations in conjunction with this assessment's findings. This assessment validated the availability of the 13 commodities in three districts at district, sub-district, and community levels, and within drug stores, in in 15 government facilities and 27 private drug stores in August and September 2013. Key stakeholders (including Ministry of Family Health and Welfare and government officials, members of professional associations, and non-governmental representatives) were consulted. A national workshop stimulated discussion, identified national priorities and information gaps, and identified areas requiring policy review. This stakeholder engagement helped identify opportunities for their organizations' contributions to implementing the UN Commission recommendations.

\section{FINDINGS}

\section{Regulatory issues}

The assessment determined that Bangladesh has well-developed policies to regulate production, distribution, sale, and use of all drugs as well as ensuring they are of good quality, efficacious, and safe. It is also revealed that all drugs, medicines, and other mechanical substances in final dosage forms (those manufactured, imported, distributed, marketed, or consumed in the country) must be registered with the regulatory authoritythe Directorate General of Drug Administration. The the registration must specify dosage form and strength, according to the country's Drug Control Committee (a committee of the Directorate General of Drug Administration). The Directorate General of Drug Administration's capacity seems to be logistically limited and lacks skilled manpower, while other regulatory factors including pharmaceutical companies' individual operating procedures, quality control, and quality assurance programs complicate regulatory issues.

\section{Registration and commodity availability}

The assessment found that many policymakers and program managers are not aware of the UN Commission report nor its recommendations. Stakeholders who were aware were generally from international and UN organizations and involved in actual implementation of the Commission's recommendations.

With the exception of the female condom, however, each of the 13 life-saving commodities is registered and available in Bangladesh. Not all of maternal and neonatal commodities are registered in the dosage forms recommended by the World Health Organization for their specified indications, nor do service delivery guidelines provide indications for their use.

Availability and shortage need to be addressed. Oxytocin and Misoprostol were not available in two out of three district hospitals visited but were available in all Mother and Child Welfare Centers. Similarly, Misoprostol was not available in any Union Health and Family Welfare Centers or Community Clinics visited.

Although Oxytocin is available and used for induction of labor and preventing postpartum hemorrhage in most district and sub-district facilities (although not in community facilities), consistent lack of cold chain storage necessary for the drug's integrity remains a significant challenge. Many government facilities and most private drug stores lack functioning refrigerators. Often Oxytocin is stored on an open shelf, rendering it ineffective. 
Misoprostol is registered in Bangladesh and, in recent years, was introduced and scaled up for postpartum hemorrhage prevention and management at the community level. Service Delivery Guidelines are available for community use. Thus far, 19 out of 64 districts have the Guidelines. Discussions are ongoing to bundle Misoprostol with safe delivery kits.

Magnesium sulphate is registered for prevention and treatment of severe pre-eclampsia and eclampsia, but it was not available in one out of two Mother and Child Welfare Centers and two out of five Upazila Health Complexes visited. Service delivery guidelines are available for community service providers. Community service providers tend to prefer single dose solutions for intramuscular injection in a pilot study underway in two sub-districts and upazilas, rather than other dosages or formulations. Population Council is currently conducting a study to determine whether it is feasible and acceptable for community service providers to administer an intramuscular loading dose of magnesium sulfate before referral.

Several injectable antibiotics, including those recommended by the United Nations Commission, including amoxicillin for treatment of pneumonia, are registered and available in various dosage forms for treating neonatal sepsis and other infectious conditions. Injectable antibiotics were not available in one out of three District Hospitals, no Mother and Child Welfare Centers, nor two out of five Upazila Health Complexes.

Chlorhexidine is registered and available in various dosage forms but not in the concentration necessary for neonatal cord care. Chlorhexidine 7.1\% is not included in the country's Essential Drug List or Dietary and Drug Supply Kits, and no Service Delivery Guidelines are available. Although the antenatal corticosteroids dexamethasone and betamethasone are registered and available in the country in various dosage forms, the available dosage forms are not suitable for pre-term respiratory distress syndrome and are not included in the Essential Drug List, and no Service Delivery Guidelines are available.

Encouragingly, the National Core Committeef for Neonatal Health of the Directorate General of Health Services and the Directorate General of Family Planning's National Technical Committee have approved piloting and scale up in one district of the required dose of dexamethasone for pre-term respiratory distress syndrome and Chlorhexidine $7.1 \%$ for neonatal cord care. Service Delivery Guidelines are being prepared.

Oral rehydration salts and zinc are widely available as over-the-counter products and are used for diarrhea. Both are included in the Essential Drug List, and Service Delivery Guidelines are available.

Resuscitation devices for newborn asphyxia have been distributed to 19 districts. The devices were available in two out of three District Hospitals, one out of two Mother and Child Welfare Centers, three out of five Upazila Health Complexes, two out of four Union Health and Family Welfare Centres, and no Community Clinics visited. Resuscitation devices for newborn asphyxia were not found in any private drug stores.

Two types of contraceptive implants are registered. A single rod implant (Implanon) is registered and used in the government program, while a two rod implant, Jadelle (as I-plant), is registered and marketed in the private sector through Social Marketing Company. These are included in the country's approved contraceptive methods and Service Delivery Guidelines are widely available. Although there is no domestic manufacturing of implants, there were no supply shortages of implants in the facilities visited.

Emergency Contraceptive Pills are registered and have been used in Bangladesh for the last decade as an over-the-counter product, free of cost in the government program. Supplies are obtained from four domestic pharmaceutical companies, as well as imports, yet actual supplies in facilities are inconsistent. Although Emergency Contraceptive Pills were available in private drug stores, the drug was unavailable in government facilities.

The female condom is not registered in Bangladesh, as policymakers and program managers consider it unsuitable for the local context. 


\section{Challenges Identified}

- Shortages of all essential drugs and commodities in public health facilities;

- Inappropriate storage of oxytocin (and subsequent use of an ineffective drug during crucial medical events) is widespread;

- Unavailability of antenatal corticosteroids in correct dosage forms (6 mg injection) for pre-term respiratory distress syndrome; unavailability of Chlorhexidine in the correct concentration (7.1\%) for newborn cord care; provider use of inappropriate concentration; and lack of related Service Delivery Guidelines;

- Unavailability of magnesium sulfate in appropriate dose forms; manufacture of a single loading dose for severe pre-eclampsia and eclampsia is needed, but pharmaceutical companies lack interest;

- Lack of advocacy with pharmaceutical companies for manufacturing less profitable but essential drugs in appropriate dosage forms;

- Lack of awareness of Emergency Contraceptive Pills due to lack of educational efforts;

- Lack of knowledge and low use of zinc sulphate for neonatal diarrhea;

- Absence of a Directorate General of Family Planning forum for advocating for mothers and ensuring access to and use of essential maternal health drugs and commodities.

\section{Opportunities Identified}

- All 13 life-saving drugs and commodities are registered (except female condom) in the country in different dosage forms, which means that additional, altered dosage forms is feasible.

- The Directorate General of Drug Administration is very much in favor of ensuring the availability, quality, and affordability of essential maternal and neonatal health drugs and commodities. The Directorate requested an application for the approval of essential drugs in required dose forms. The Directorate General of Family Planning was requested to form an advocacy forum to ensure availability of maternal health drug and commodities, and Systems for Improved Access to Pharmaceuticals and Services supported a Forecasting Working Group in the Directorate. The Directorate General of Health Services has a Supply Chain Coordination Forum that coordinates with the United Nations, World Bank, the Joint United Nations Programme on HIV/AIDS, the Ministry of Family Health and Welfare, and other stakeholders.

- Chlorhexidine has already been approved by the Directorate General of Drug Administration in the appropriate concentration, and the National Core Committee for Neonatal Health of the Directorate General of Health Services and the Directorate General of Family Planning's National Technical Committee have approved its use in the vertical program. Social Marketing Company has reportedly begun manufacturing the drug, and Save the Children is piloting product use in one district.

- The National Core Committee for Neonatal Health of the Directorate General of Health Services and the Directorate General of Family Planning's National Technical Committee have approved the introduction and scale up of dexamethasone sodium sulphate $6 \mathrm{mg}$ intramuscular injection for pre-term respiratory distress syndrome for both facilities and use within communities.

- The Directorate General of Drug Administration has issued a letter for the appropriate storage of oxytocin in all public health facilities. The Directorates General of Health Services and Family Planning have also issued guidance to all facilities.

- Systems for Improved Access to Pharmaceuticals and Services and other stakeholders are facilitating both the Directorate General of Health Services' and the Directorate General of Family Planning's quantification of maternal and neonatal commodities needed for the facility level. The Directorate General of Family Planning 
has a logistics managment and information system for tracking the 13 recommended commodities, and they have also proposed including Chlorhexidine and misoprostol in standard infant delivery kits.

- Participating respondents are concerned about the unavailability and inappropriate dosage forms of maternal and neonatal commodities, which suggests a wide basis of support for improved commodity availability.

- Participating respondents are concerned about the use of low dose misoprostol for postpartum hemorrhage prevention and treatment.

- Social Marketing Company and EngenderHealth's Mayer Hashi program have initiated training to insert and remove implants through private providers.

\section{Recommendations}

\section{For Maternal Health}

- Misoprostol should be bundled with birthing delivery kits.

- Manufacture of a single loading dose of the magnesium sulfate solution should be consistently advocated for with pharmaceutical companies.

- Stakeholders suggest an assessment of the effectiveness of $400 \mathrm{mcg}$ versus $600 \mathrm{mcg}$ misoprostol for preventing postpartum hemorrhage among Bangladeshi women.

- Essential drugs and commodities for mothers should be made available at Union Health and Family Welfare Centres where normal vaginal deliveries are planned and conducted.

\section{For Neonatal Health}

- Chlorhexidine should be bundled with birthing delivery kits.

- Resuscitation devices should be available in all districts, particularly in all facilities where deliveries are conducted.

- Advocacy should be conducted with pharmaceutical companies for manufacture of a single dose of gentamycin injection and $7.1 \%$ Chlorhexidine.

- Essential drugs and commodities for neonates should be made available in Union Health and Family Welfare Centres, where normal vaginal deliveries are planned and conducted.

- Single doses of injectable antibiotics should be manufactured and promoted for neonatal sepsis.

- Educational efforts should be strengthened for increasing awareness of zinc use in diarrheal diseases.

\section{For Family Planning Commodities}

- The Directorate General of Family Planning should increase public awareness how to avoid unplanned pregnancies and ensure availability of Emergency Contraception, including provision for field workers.

\section{General recommendations}

- A forum at the Directorate General of Family Planning should be formed to advocate for ensuring access to and use of maternal and newborn drugs and commodities.

- Further initiatives are necessary for ensuring drug quality, dosage appropriateness, and reliable availability in both the private and public sectors.

- The Directorates General of Drug Administration, Family Planning, and Health Services should be regularly updated by active stakeholders on global updates in maternal and neonatal health and other public health issues. 


\section{Background}

The United Nations (UN) Secretary General's Global Strategy for Women's and Children's Health 2010 report highlighted the lack of access to life-saving commodities resulting in preventable deaths of women and children. The Strategy called on the global community to work together to save 16 million lives by 2015 through increasing access to and appropriate use of essential medicines, medical devices and health supplies during pregnancy, childbirth, the postnatal period, and childhood.

The UN secretary General convened the UN Commission on Life-Saving Commodities for Women and Children (the Commission), which is a part of the Every Woman, Every Child movement, with the overall goal of increasing access to life-saving commodities in 50 of the world's poorest countries. The Commission identified and endorsed an initial list of 13 overlooked life-saving commodities that, if more widely accessed and properly used, could save the lives of more than six million women, newborns, and children, including prevention of 1.8 million child deaths annually and 230,000 maternal deaths, through increased access to family planning (FP) around the world. The 13 commodities identified include oxytocin and misoprostol for postpartum hemorrhage $(\mathrm{PPH})$, Magnesium sulphate $\left(\mathrm{MgSO}_{4}\right)$ for severe pre-eclampsia and eclampsia, injectable antibiotics for newborn sepsis, Antenatal corticosteroids (ANCS) for pre-term respiratory distress syndrome, chlorhexidine for newborn cord care, resuscitation devices for newborn asphyxia, amoxicillin for pneumonia, oral rehydration salts (ORS) and zinc for diarrhea; and female condoms, contraceptive implants, and emergency ontraceptive pills (ECPs) for contraception.

The Commission also identified key interrelated barriers that prevent access to and use of the 13 commodities, which severely under-resourced regulatory agencies in low-income countries, leading to delayed registration of commodities; lack of oversight of product quality and general inefficiencies; market failures, where return on investment is too low for encouraging manufacturers to enter the market or produce sufficient quantities; and user supply and demand challenges such as limited demand for the product by end users, local delivery problems, and incorrect prescription and use. To address these challenges and deliver on the promise of saving the lives of millions of women, newborns, and children, the Commission recommended ten actions to be achieved within definite preriods of time. These actions focus on the need for improving global and local markets for life-saving commodities, innovative financing, quality strengthening and regulatory efficiency, improved national commodity delivery, and better integration of private sector and consumer needs.

In Bangladesh, 12 of the 13 commodities are registered (except female condoms), but the extent to which these commodities are available at point of presacription and use, their doses and forms, policies for use, client access, and awareness are not widely, particularly at the district level. Furthermore, little is known about health workers' knowledge and technical competencies. Bangladesh's Ministry of Health and Family Welfare (MoHFW) comprises two divisions: the Directorate General of Health Services (DGHS), responsible for ensuring availability of maternal child health drugs, supplements, and devices; and the Directorate General of Family Planning (DGFP), which is responsible for ensuring contraceptive availability. DGFP is also responsible for ensuring availability of maternal child health drugs, supplements, and devices, in addition to contraceptives, at health facilities. The Directorate General of Drug Administration (DGDA) under MoHFW is the country's Drug Regulatory Authority.

Globally, efforts are underway to implement the UN Commission recommendations on Life-Saving Commodities for Women and Children. In an effort to contribute to the Government of Bangladesh's implementation plan for these recommendations, Population Council, with support from the Hewlett Foundation, assessed the availability of the 13 life-saving commodities to provide empirical information for decision making within the country's health sector. 


\section{Objective}

This assessment's primary objective was to examine the policies, guidelines, and availability for the 13 identified life-saving commodities in Bangladesh as well as engaging with policymakers and program managers in implementing the UN Commission recommendations in light of the assessment's findings. This assessment's findings are expected to be used as to stimulate discussion, identify national priorities and information gaps, influence policy formulation, and increase access to the commodities and assist international advocates for global advocacy. The specific objectives of this exercise are to:

- Engage with national leaders on determining national priorities and information gaps about the 13 maternal and neonatal health products;

- Examine policies and guidelines of the 13 life-saving commodities;

- Explore procurement mechanisms of the 13 life-saving commodities/supplies;

- Explore manufacturing capacity, availability of quality assurance guidelines and policies, product packaging policies, distribution mechanisms, cost to end users and financing;

- Examine access to and availability of the 13 life-saving commodities at public sector facilities at district, subdistrict, and community levels, as well as at private drug stores;

- Assess stakeholders' and professional associations' interest and participation in ensuring commodity supplies; and

- Stimulate discussion among decision makers and help identify policy options for increasing commodity access and availability. 


\section{Methodology}

This Maternal Health Commodity Landscaping Exercise comprised two activities: assessing and providing a comprehensive description of maternal and neonatal health $(\mathrm{MNH})$ commodity issues, from policy formulation to point of care; and engaging stakeholders for implementing the UN Commission recommendations. The study's methodology included a document review of the policies, service guidelines, and availability and use of the 13 life-saving commodities as well as validating the availability of those commodities in district, subdistricts, and community facilities and private drug stores. Stakeholders provided recommendations regarding the areas of assessment along with susequent discussion of the results and identification of priority actions.

\section{NATIONAL ASSESSMENT}

\section{Document review of policies, guidelines, and use of 13 life-saving commodities}

Policy documents, policies, service delivery guidelines and circulars were collected and reviewed, complemented by searches for drug manufacturers at www.bddrugs.com and pharmaceutical companies' web sites, as well as www.dgda.gov.bd, the Directorate General of Drug Administration's web site (Appendix 1). These document reviews and searches were further complemented by 21 in-depth interviews with representatives from MoHFW, professional associations and bodies, development partners, pharmaceutical companies, and NGOs, for clarification and greater detail about the drug and commodity landscape in Bangladesh. The findings from these searches and interviews combined to described the availability of the 13 recommended commodities, as well as related policy gaps, existing procurement mechanisms, manufacturing capacity, quality assurance guidelines and policies including product packaging, distribution and logistics, costs for end users, and financing. These activities provided mechanisms for engaging national and regional stakeholders and professional associations in ensuring supplies, identifying national priorities, and information gaps.

\section{Availability of the 13 life-saving commodities}

District, sub-district and community public facilities as well as private drug stores were visited to determine if the 13 recommended commodities were available. Public drug stores were also visited to assess commodity availability, stock outs, and drug storage (including humidity and temperature control and refrigeration). A checklist was used to collect this information. Fifteen government facilities from three districts were visited including three District Hospitals, two Maternal and Child Welfare Centers (MCWCs), five Upazila Health Complexes (UHCs), four Union Health and Family Welfare Centers (UH\&FWCs), and one Community Clinic (CC). Twenty-seven private drug stores were visited for information on drug availability, indications for which they are sold, and price; 16 of the 27 drug stores were at the district level and 11 were at the sub-district level.

\section{DOCUMENTS REVIEWED}

- Drug Policy of the Government of Bangladesh, MoH\&FW

- Quality Manual of Directorate General of Drug Administration, Bangladesh, MoH\&FW

- DGHS and DGFP operation plan 2011-2016, MoH\&FW

- "Training Manual of Use of Misoprostol to Prevent Postpartum Hemorrhage (PPH)," MoH\&FW, USAID, EngenderHealth.

- "Information Kit on Use of Misoprostol to Prevent PPH at Home Delivery," MoH\&FW and EngenderHealth

- "National Protocol for Providing Loading Dose of Magnesium Sulphate $\left(\mathrm{MgSO}_{4}\right)$ by the Community Level Service Providers," MoH\&FW, Obstetrical and Gynecological Society of Bangladesh (OGSB), EngenderHealth, Maternal and Child Health Integrated Program (MCHIP), and Population Council

- “Family Planning Manual," Directorate General of Family Planning (DGFP), MoH\&FW

- Trainer's Handbook, "Active Management of Third Stage of Labor," MoH\&FW

- Minutes of National Core Committee, Neonatal Health (NCC-NH), MoH\&FW

- Minutes of National Technical Committee (NTC), DGFP

- Revised supply manual (2013), DGFP 


\section{STAKEHOLDER ENGAGEMENT}

A half day national workshop on 8 October 2013 in Dhaka with 22 policymakers, program managers, regulators, pharmaceutical industry representatives, and other stakeholders shared and discussed the findings of the assessment and identified priority activities for implementing the UN Commission's recommendations within the Bangladeshi context.

In addition to Population Council's presentation, two other organizations presentated information on maternal and neonatal health commodity issues.

The sessions enabled the Council to engage with DGFP, DGHS, and other stakeholders, to sensitize them to the Commission's recommendations and exploring their introduction in Bangladesh, as well as providing an opportunity for developing recommendations that emerged from the workshop and discussing them.

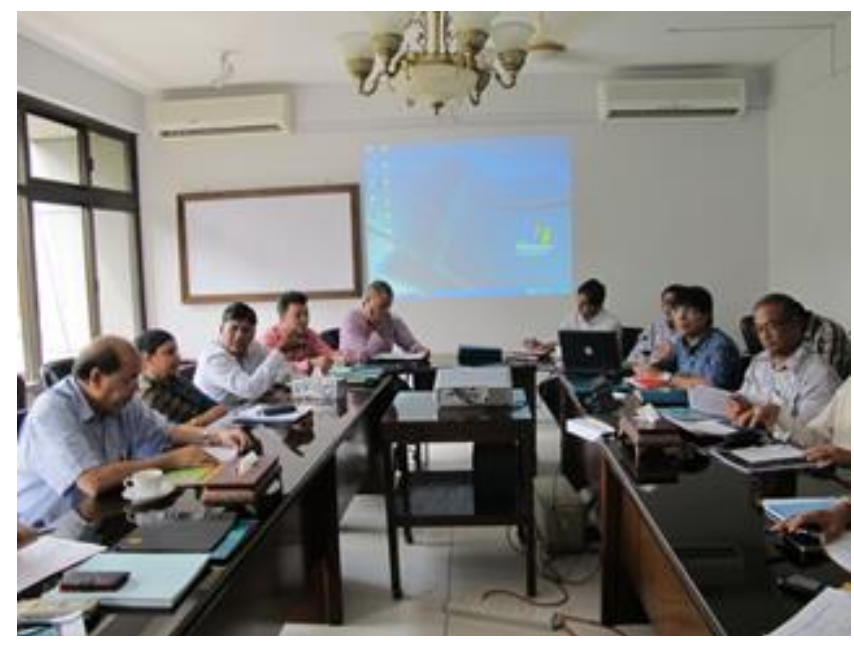

Workshop participants 


\section{Results}

The findings of this report triangulate the results from the review of policy documents, in-depth interviews, at facility and drug store validation assessments, the validation workshop, and findings from the efforts to engage policy makers, program managers, and other stakeholders in implementation of the UN Commission recommendations.

\section{NATIONAL DRUG POLICY}

\section{Drug policies and guidelines}

The Directorate General of Drug Administration (DGDA), a division of MoHFW, is Bangladesh's Drug Regulatory Authority. Interviews with DGDA officials revealed that it controls and regulates production, distribution, sale, and use of any drugs in the country. DGDA's primary responsibility is to ensure that drugs are safe, efficacious, and of good quality. The National Drug Policy was formulated in 1982, and currently the Drugs Act 1940 (XXIII of 1940) and Drugs (control) Ordinance 1982 (VIII of 1982) regulates registration, manufacturing, distribution, sale, importation, and exportation of any drugs in Bangladesh.

All drugs, medicines, and other mechanical substances in final

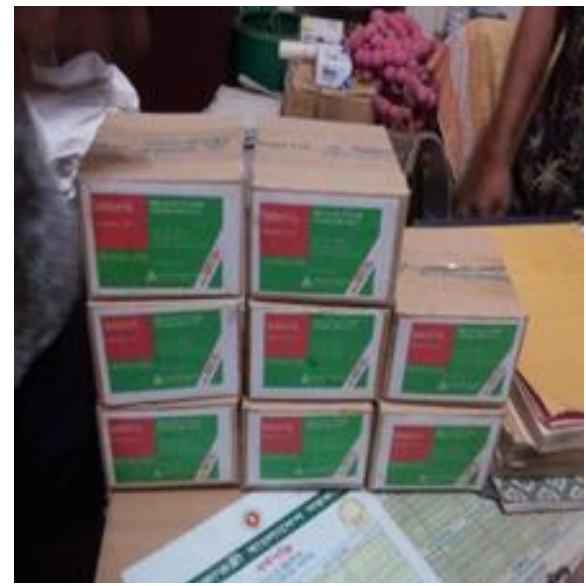

Oxytocin supply at a facility dosage forms manufactured, imported, distributed, marketed, or consumed in Bangladesh must be registered with DGDA for the specific dosage form and strength recommended by the Drug Control Committee (of DGDA). An important objective of the National Drug Policy is to make good quality drugs available at affordable prices, and therefore the policy requires quality assurance at different stagesmanufacturing, transit, and storage, with testing at different times before it reaches the end user.

Interviews with policy makers and program mangers suggest that those responsible for implementing maternal health policies and services were not aware of the specifics of maternal health commodity policies and the UN Commission report and its recommendations. A few stakeholders, particularly the international development organizations and UN agencies, are aware of UN Commissions' recommendations.

\section{Drug registration, indications, dose forms and presentations, and essential drugs list}

All 13 life-saving commodities are registered in Bangladesh with the exception of female condoms. Some of the commodities are not registered in the specific dose forms needed for particular MNH conditions or indications. A feasibility and acceptability study of the female condom by Social Marketing Company produced results that were not compelling enough to merit its introduction; policymakers and program managers suggested that the female condom would not have substantial uptake in Bangladesh.

Oxytocin and magnesium sulphate are reported as registered and in use throughout the country for a long time. Oxytocin is registered for induction of labor and PPH prevention and treatment, available in 5 $\mathrm{iu} / 1 \mathrm{ml}$ ampoules, for both IM and IV injections, and in tablet form. Only one pharmaceutical company manufactures oxytocin tablet, and it is perceived as less effective than injection for the same indications. Service delivery guidelines (SDGs) for oxytocin are in place and followed in all facilities.

Magnesium sulphate $\left(\mathrm{MgSO}_{4}\right)$ is registered for prevention and treatment of severe pre-eclampsia (SPE) and eclampsia and is available at $49.3 \% \mathrm{w} / \mathrm{v}$ in $5 \mathrm{ml}$ ampule (2.46 gm) and 4\% w/v in 16.4

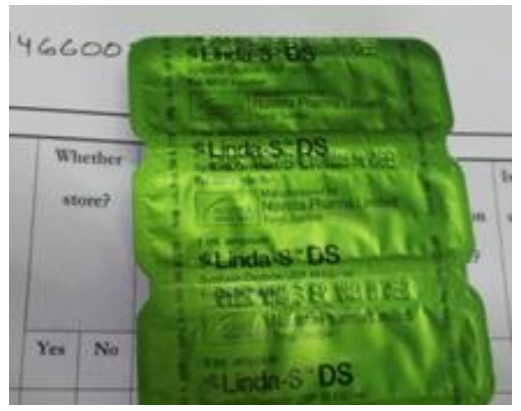

Oxytocin tablets $\mathrm{mmol}$ or $4.0 \mathrm{gm} / 100 \mathrm{ml}$ solution for injection and infusion (IV/IM) forms (Table 3a and Table 3b). Although $\mathrm{MgSO}_{4}$ is registered and used for preventing and treating SPE and eclampsia, it is not available for this 
indication as a single loading dose (10 $\mathrm{mg} I \mathrm{~V} / \mathrm{IM})$ at the community level. Two studies, at the request of the National Technical Committee, are operationalizing and assessing the ability of community service providers to detect, prevent, and treat SPE and eclampsia with a single loading dose of $\mathrm{MgSO}_{4}$ before referral. Magnesium sulfate SDGs, for use by providers in community facilities, have been developed by MoHFW, the Obstetrical and Gynecological Society of Bangladesh, EngenderHealth, and Save the Children, and are being tested $^{1}$.

Misoprostol is registered, in two tablet dose forms (100 mcg, and $200 \mathrm{mcg}$ ), for gastrointestinal indications. Recently manufacturers' brochures have included indications such as labor induction, PPH prevention and treatment, abortion induction, abortion incompletion, miscarriage, postabortion care, and intrauterine fetal death for which cervical ripening or softening is required.

Although WHO, FIGO, and other professional bodies have recommended $600 \mathrm{mcg}$ of Misoprostol for PPH prevention and management, the dosage approved by the National Technical Committee is $400 \mathrm{mcg}$. The National PPH Prevention Task Force and other relevant stakeholders recommended the lower dose based on Bangaldeshi women's shorter stature and lower weight, but whether $400 \mathrm{mcg}$ effectively prevents or treats PPH has not been evaluated. Anecdotal evidence suggests the $400 \mathrm{mcg}$ dosage is ineffective, meriting its reevaluation. Single $400 \mathrm{mcg}$ doses are available in individual packages for PPH prevention and treatment. Misoprostol $400 \mathrm{mcg}$ is being scaled up in phases in another 18 districts. DGFP has included procurement (1.8 million pills or the equivalent of 0.9 million doses have already purchased) and distribution of Misoprostol in its operational plan (OP), and SDGs are available ${ }^{2}$, and Misoprostol tablets are now included in the country's Essential Drug List (Appendix 2).

As in other developing countries, fatality rates for severe bacterial infections in neonates (neonatal sepsis) are high in Bangladesh, partially due to the unavailability, or late or inadequate administration, of necessary antibiotics $^{3,4}$. The UN Commission identified the three (procaine benzyl penicillin, gentamicin sulphate, ceftriaxone) most cost-effective antibiotics for neonatal sepsis. WHO recommends antibiotic treatment with procaine benzyl penicillin and gentamicin as initial therapy for presumptive treatment in newborns at risk of bacterial infection ${ }^{5}$. WHO recommends intramuscular injections (IM) of $50 \mathrm{mg} / \mathrm{kg}$ body weight of ampicillin (or a comparable penicillin such as procaine benzyl penicillin) every six to eight hours, depending on age, plus $7.5 \mathrm{mg} / \mathrm{kg}$ body weight of gentamicin (or another comparable aminoglycoside), divided twice daily for at least 10 days, as the standard therapy ${ }^{6}$. WHO also recommends, as a secondary therapy, daily injection of a single dose of ceftriaxone ${ }^{7}$ alone, of $50 \mathrm{mg} / \mathrm{kg}$ body weight for all newborns except those older than one week and weighing more than two kgs. In those slightly older and heavier newborns, the daily dose is increased to $75 \mathrm{mg} / \mathrm{kg}$ for 10 days. ${ }^{8}$

In Bangladesh amoxicillin is available in many forms-powder for suspension, drops, tablet and injection-for pneumonia treatment. Procaine benzyl penicillin, gentamicin sulphate, ceftriaxone, and amoxicillin are each registered and indicated for newborn sepsis and other life-threatening infections. Procaine benzyl penicillin, gentamicin sulphate, and amoxicillin are listed in the EDL, but ceftriaxone is not (Appendix 2). The available doses for procaine benzyl penicillin are procaine penicillin 3 lac and benzyl penicillin 1 lac/vial for IM injection; $20 \mathrm{mg}$ and $80 \mathrm{mg}$ of gentamycin sulphate for IM/IV injection and 250, 500, 1,000, and 2,000 mg of ceftriaxone for IM/IV injection. Amoxicillin is available in the dose forms of $100 \mathrm{mg} / 1 \mathrm{ml}$ drop, $125 \mathrm{mg} / 5$ $\mathrm{ml}$ suspension, 250/500 mg/vial IM/IV injection and $250 \mathrm{mg} /$ tablet dispersible tablet. SDGs are available

1 MoHFW, OGSB, Save the Children (MaMoni project), and EngenderHealth. 2011. Guideline for prevention and management of pre-eclampsia and eclampsia at the Community. Guideline for community level service providers. EngenderHealth: Dhaka.

2 MoHFW, EngenderHealth, Bangladesh and The National PPH Prevention Task Force. 2009. Guideline on Misoprostol Use in Bangladesh to prevent PPH at the Community level. EngenderHealth: Dhaka.

3 Thaver D, Zaidi AK. Burden of neonatal infections in developing countries: a review of evidence from community-based studies. Pediatric Infectious Disease Journal. 2009;28(S1):S3-S9.

4 Neonatal sepsis web page. Merck Manual website. Available at: www.merckmanuals.com/professional/pediatrics/infections_in_neonates/neonatal_sepsis.html\#v1092175.

5 Procaine benzyl penicillin is not recommended as first-line treatment for neonatal sepsis except in settings with high neonatal mortality, when given by trained health workers in cases where hospital care is not achievable.

6 WHO. Management of the Child With a Serious Infection or Severe Malnutrition: Guidelines for Care at First Referral Level in Developing Countries. Geneva: WHO; 2000: 62.

7 WHO recommends not to administer with calcium and avoid in infants with hyper-bilirubinemia.

8 Saez-Llorens X, McCracken GH. Clinical pharmacology of antibacterial agents. In: Remington JS, Klein JO, eds. Infectious Diseases of the Fetus and Newborn Infant. Philadelphia: W.B. Saunders Company; 2001: 1419-1466. 
for all four drugs. During the sixth meeting of DGHS's National Core Committee for Neonatal Health (NCC-NH) (2 September 2013) including dispersible amoxicillin tablet in the EDL was suggested ${ }^{9}$. Similarly, DGFP's 61 $1^{\text {st }}$ National Technical Committee (26 November 2013) approved amoxicillin dispersible tablets for the Dietary and Drug Supply (DDS) Kit10 of primary health and FP facilities for treating neonatal sepsis.

For women at risk of pre-term delivery within seven days, WHO recommends a single course of corticosteroids between 24 weeks and 34 weeks of gestation. ${ }^{11} \mathrm{~A}$ single course of antenatal corticosteroids (ANCS) should be administered to women with premature rupture membranes before 32 weeks of gestation to reduce risk of pre-term respiratory distress syndrome (PTRDS), perinatal mortalities, and other morbidities. Dexamethasone sodium phosphate and betamethasone sodium phosphate are the two ANCS's recommended for accelerating fetal lung development in threatened pre-term birth. WHO, NIH, ACOG, RCOG, and WAPM list both as effective drugs for preventing complications of prematurity, using either a dosage of $24 \mathrm{mg}$ of dexamethasone IM injection (4 doses of $6 \mathrm{mg} 12$ hours apart) or $24 \mathrm{mg}$ of betamethasone IM injection (2 doses of $12 \mathrm{mg} 24$ hours apart) ${ }^{12,13}$. As of April 2013, the $18^{\text {th }}$ edition of the WHO Model List of Essential Medicines, which for the first time includes antenatal corticosteroids, lists only dexamethasone sodium phosphate for fetal indications ${ }^{14}$.

The ingredients for antenatal corticosteroids (dexamethasone sodium phosphate and betamethasone sodium phosphate) are registered in Bangladesh in different dose forms and for various indications, but not for pre-term respiratory distress syndrome (Table 3a and Table 3b). SDGs for the other indications are available, but not for pre-term respiratory distress syndrome. Dexamethasone sodium phosphate and betamethasone sodium phosphate are registered as $0.5 \mathrm{mg}$ tablet, $0.1 \%$ eye drop, $0.05 \%$ eye ointment, and $5 \mathrm{mg}$ injection (only dexamethasone) dose forms for various indications, but not in $6 \mathrm{mg}$ dose form as injection, which is indicated for pre-term respiratory distress syndrome. Although dexamethasone and betamethasone are listed in the EDL, $6 \mathrm{mg}$ dose is not. DGHS's sixth National Core Committee for Neonatal Health meeting approved introduction and scale up of $6 \mathrm{mg} I \mathrm{M}$ injection of dexamethasone for pre-term respiratory distress syndrome at the facility and community levels ${ }^{15}$. Pilot testing is ongoing in one district for assessing the feasibility and efficacy of ANCS in pre-term respiratory distress syndrome. Save the Children is working with DGHS, DGFP, and pharmaceutical companies to make the available dose form and include SDGs.

Chlorhexidine digluconate, a broad spectrum antiseptic, is commonly used worldwide for various indications. WHO added 7.1\% Chlorhexidine digluconate (delivering 4\% Chlorhexidine) to the 2013 Model List of Essential Medicines for Children under Specific Medicines for Neonatal Care (Section 29) for neonatal cord care. Chlorhexidine cord cleansing ( $7.1 \%$ chlorhexidine digluconate) should not to be confused with other Chlorhexidine interventions using Chlorhexidine gluconate, such as solution for vaginal cleansing $(0.16 \%-$ $0.60 \%)$, neonatal skin wiping $(0.16 \%-0.60 \%)$, eyewash $(0.05 \%)$, dental wash $(0.12 \%)$, or preoperative skin cleansing (2.0\%).

Chlorhexidine gluconate is registered in different dose forms for various indications in Bangladesh, but not for newborn cord care; it is listed in the EDL for the other indications (Appendix 2), with SDGs available. Although they are not effective for cord care, the available dose concentrations are widely used in Bangladesh for newborn cord cleansing. The appropriate dose form (7.1\%, according to WHO) for cord cleansing has been shown to be highly effective in the region: Three community-based randomized control trials in Nepal, Bangladesh, and Pakistan resulted in Chlorhexidine cord cleansing's substantial reduction of neonatal mortality in all three countries, by 24 percent in Nepal, 20 percent in Bangladesh, and 38 percent

\footnotetext{
9 DGHS, MoHFW.2013. Minutes of the $6^{\text {th }}$ meetings of the National Core Committee for Neonatal Health. Dhaka: DHGS.

10 DDS Kit is a box containing 26 pre-selected essential drugs, and dietary items to be dispensed by the community-based facility level service providers at UH\&FWCs for patient management. Each month they receive certain number of DDS Kits from the central warehouse.

11 Threatened pre-term birth can be characterized by four signs and symptoms that include i) fluid leaking from vagina (rupture membrane); ii) painful uterine contractions; iii) antepartum haemorrhage (vaginal bleeding); and iv) signs and symptoms of severe pre-eclampsia and eclampsia.

12 WAPM: Guideline for the use of antenatal corticosteroids for fetal maturation (2008). (Xavier Miracle1, Gian Carlo Di Renzo, Ann Stark, Avroy Fanaroff, Xavier Carbonell- Estrany1 and Erich Saling. J. Perinat. Med. 36 (2008). New York.)

13 Cochrane summary: Antenatal corticosteroids for accelerating fetal lung maturation for women at risk of preterm birth.

14 WHO Model List of Essential Medicines, $18^{\text {th }}$ list (April 2013).

15 DGHS, MoHFW.2013. Minutes of the $6^{\text {th }}$ meetings of the National Core Committee for Neonatal Health. Dhaka: DHGS.
} 
in Pakistan. Chlorhexidine cord cleansing also reduced severe cord infection by 75 percent in Nepal, 65 percent in Bangladesh, and 42 percent in Pakistan.

DGHS's sixth National Core Committee for Neonatal Health meeting, prior to the stakeholder meeting, was a turning point, at which application to all newborn umbilical stumps at birth ${ }^{16}$ of $7.1 \%$ aqueous solution of Clorhexidine gluconate, regardless of place of birth (home or facility), was approved and listed as part of the essential neonatal care (ENC) package. The committee also suggested including $7.1 \%$ Chlorhexidine in the EDL. Similarly, DGFP's $61^{\text {st }}$ National Technical Committee meeting approved Chlorhexidine $7.1 \%$ aqueous solution's inclusion in primary health and FP care facilities' Dietary and Drug Supply (DDS) Kits for newborn cord care. Save the Children is scaling it up in one district, and SDGs are being prepared. Dialogue is being initiated with reputed pharmaceutical companies to encourage the production and marketing of aqueous solution of $7.1 \%$ Chlorhexidine nationwide. ${ }^{17}$

Almost half of all newborn deaths occur within the first 24 hours, with most resulting from birth asphyxia due to intra-partum complications. This condition, manifesting as newborn failure to establish breathing after birth, is responsible for one quarter of all newborn deaths worldwide each year ${ }^{18}$. Many of these deaths could be easily prevented with basic neonatal resuscitation, which requires tactile stimulation, a neonatal bag and mask, suction device, and a resuscitation training mannequin. With this basic equipment and effective pre- and in service training, successful resuscitation of newborns is possible for about 30 percent of cases otherwise resulting in death among full term babies, and for five to ten percent of pre-term births ${ }^{19}$.

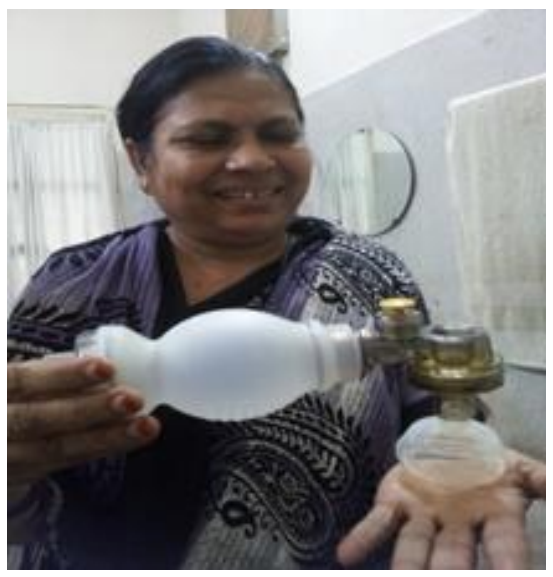

Resuscitation device

The WHO Essential Medical Devices List, which is currently being updated for priority interventions for Maternal, Neonatal and Child Health, includes neonatal resuscitators (self-inflated bag and mask), suction devices, and resuscitation training mannequins. The resuscitation device is registered in Bangladesh, but there is no Essential Medical Devices List in Bangladesh. The device has been donated by USAID in selected districts under the Helping Babies Breathe (HBB) program implemented by DGHS, ICDDR,B, and Save the Children, with technical assistance from UNICEF. SDGs are available.

Oral Rehydration Salts (ORS), introduced in Bangladesh by ICDDR,B, are widely available and in use. ORS is registered and incorporated into the EDL

for diarrheal treatment of children, with SDGs. ORS is over-the-counter, has a strong safety profile, and has no cold chain storage requirements. The standard treatment guidelines for diarrhea in Bangladesh follow the WHO-UNICEF Integrated Management of Childhood Illnesses (IMCl) guidelines. Recently, zinc sulphate monohydrate was added for diarrhea management as an adjunct therapy, as it has proven effective in reducing diarrheal episodes, as well as their duration. Zinc is registered in Bangladesh, listed in the EDL, with SDGs available. ORS in

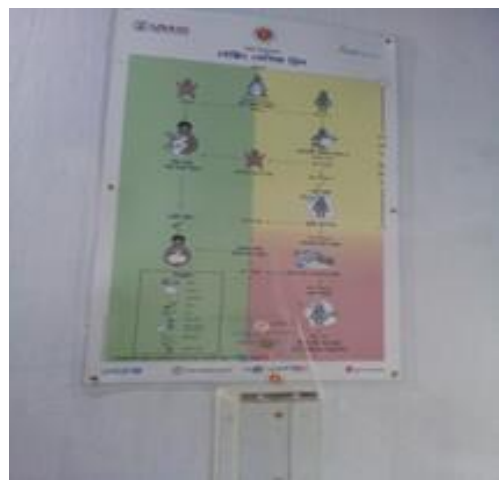

Service Delivery Guideline on resuscitation device Bangladesh is available in various forms mixed with nutritional components (under brand names such as ORSaline-N, ORSaline Fruiti, Tasti Saline), while zinc sulphate monohydrate is available in tablet and syrup, a $10 / 20 \mathrm{mg} /$ tablet or $5 \mathrm{ml}$ syrup. New WHO and UNICEF formulations of ORS have Sodium Chloride $1.30 \mathrm{gm}$, Potassium Chloride $0.75 \mathrm{gm}$, TriSodium Citrate/Dye Hydrate $1.45 \mathrm{gm}$, and Glucose/Anhydrous $6.75 \mathrm{gm}$.

16 Guidelines suggest single application of $7.1 \%$ Chlorhexidine aqueous solution followed by dry cord care.

17 DGHS, MoHFW.2013. Minutes of the $6^{\text {th }}$ meetings of the National Core Committee for Neonatal Health. Dhaka: DHGS.

18 Black, R., S. Cousens, H.L. Johnson, et al. 2010. Global, regional, and national causes of child mortality in 2008: a systematic analysis. Lancet 375(9730): 1969-1987.

19 Wall, S.N. et al. 2009. Neonatal resuscitation in low resource settings: what, who, and how to overcome challenges to scale up. International Journal of Gynecology and Obstetrics 107: S47-S64. 
The female condom is not registered in Bangladesh, and policy makers and program managers believe its acceptance and use would not be significant. Contraceptive implants and emergency contraceptive pills (ECPs) are, however, registered and included in DGFP's contraceptive method mix. SDGs for these methods are available. Two types of contraceptive implants are available: a three year single rod implant with $68 \mathrm{mg}$ etonogestrel, and a five year two rod implant, each containing $75 \mathrm{mg}$ levonorgestrel.

In Bangladesh ECPs are an over-the-counter product manufactured by several pharmaceutical companies in the country. DGFP's 61 $1^{\text {st }}$ National Technical Committee meeting in August 2013 approved a single dose (1.5 mg) ECP regimen, instead of a two dose regimen of $0.75 \mathrm{mg} /$ dose 12 hours apart, with the period of time during which women can effectively take ECPs increased to from 72 hours to 120 hours after unprotected sex. Although the drug is not listed in the EDL or in the Dietary and Drug Supply Kits for primary health care facilities, SDGs are available.

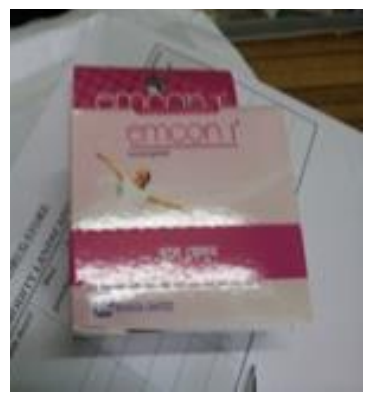

Emergency Contraception Pill

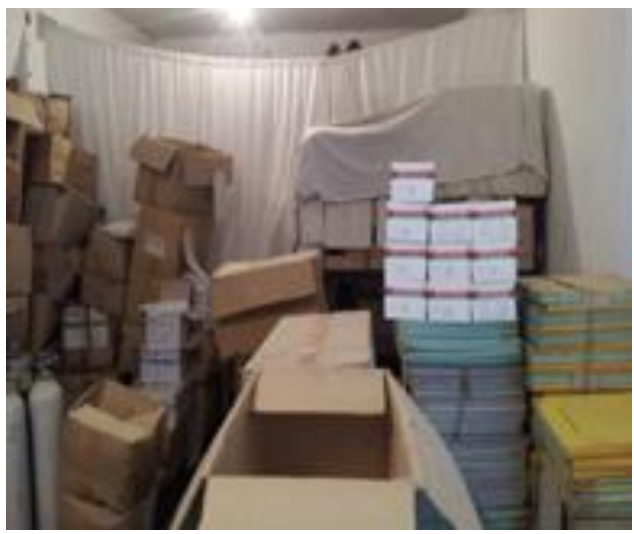

\section{DRUG AVAILABILITY}

\section{Government facilities and drug stores}

A team visited 15 public sector facilities between August and September 2013. In-depth interviews with policy makers, program managers, and other stakeholders revealed that the 13 commodities, with the exception of female condoms, can generally be found at health facilities at district, sub-district, and primary care levels. Some drugs are not available in WHO recommended doses for maternal and neonatal indications, and drugs were not available on the day of the visit at some facilities, and shortages were reported.

TABLE 1: Maternal and neonatal health drugs and commodities available in government facilities, by facility type

\begin{tabular}{lcccccc}
\hline \multirow{2}{*}{$\begin{array}{l}\text { Maternal and neonatal } \\
\text { drug or commodity }\end{array}$} & \multicolumn{4}{c}{ Dumber of facilities, by type } & \multirow{2}{*}{ Total (\%) } \\
\cline { 2 - 6 } & DH & MCWC & UHC & UH\&FWC & CC & \\
\hline Oxytocin & 1 & 2 & 4 & $0^{20}$ & $0^{21}$ & $7(47 \%)$ \\
Misoprostol & 1 & 2 & 3 & $1^{22}$ & 0 & $7(47 \%)$ \\
Magnesium sulphate & 3 & 1 & 2 & $0^{23}$ & $0^{21}$ & $6(40 \%)$ \\
Injectable antibiotics & 2 & 0 & 3 & $0^{20}$ & $0^{21}$ & $5(33 \%)$ \\
Antenatal corticosteroid & 0 & 0 & 0 & $0^{20}$ & $0^{21}$ & $0(0 \%)$ \\
Chlorhexidine & 0 & 0 & 0 & 0 & 0 & $0(0 \%)$ \\
Resuscitation device & 2 & 1 & 3 & 2 & $0^{20}$ & $8(53 \%)$ \\
Amoxicillin & 3 & 2 & 4 & 4 & 1 & $14(93 \%)$ \\
ORS & 3 & 0 & 4 & 1 & 1 & $9(60 \%)$ \\
Zinc & 3 & 1 & 2 & 1 & 1 & $8(53 \%)$ \\
Female condom & - & - & - & - & - & $8(53 \%)$ \\
Contraceptive implants & 224 & 2 & 3 & $1^{26}$ & $0^{20}$ & $0(0 \%)$ \\
Emergency contraceptive pill & 0 & 0 & 0 & 0 & 0 & 15 \\
\hline N & 3 & 2 & 5 & 4 & 1 & 0 \\
\hline
\end{tabular}

' 0 '=Not available; ' - '=Never introduced; $\mathrm{DH}=$ District hospital; MCWC=Mother and Child Welfare Center; $\mathrm{UHC}=$ Upazila Health Complex; UH\&FWC=Union Health and Family Welfare Center, $\mathrm{CC}=$ Community Clinic

20 According to MoHFW policy, these centers are not allowed to provide this drug.

${ }^{21}$ Service providers at this level are not allowed to administer any injectable antibiotic.

22 Misoprostol is in the process of scaling up with only 10 districts with community distribution thus far.

${ }^{23}$ Loading dose is approved to provide from these centers and piloting is continuing.

24 These centers can provide these services only when they are designated or upgraded to provide the services. 
Corticosteroids (dexamethasone sodium sulphate and betamethasone sodium sulphate) and Chlorhexidine were not found in MCWCs, UH\&FWCs, and CCs. Where they were available, they were not in the right dose forms for pre-term respiratory distress syndrome or newborn cord care. Resuscitation devices were available in all facilities where health professionals and workers were trained under Helping Babies Breathe (see Table 1) in 19 districts.

Antibiotic injections (amoxicillin) in different dose forms were found in most facilities, except one UHC, and no MCWCs. (Availability of ORS, zinc sulphate, and contraceptive implants are presented in Table 1.) ECPs were not available in any facilities due to supply shortages. Although some UH\&FWCs are ready to provide normal delivery services, they do not have any drugs except those in the DDS Kit (Appendix 3) such as Chlorhexidine, misoprostol, oxytocin, and $\mathrm{MgSO}_{4}$ (Table 1).

Discussions with facility managers, service providers, and store keepers revealed that SDGs for some of the 13 commodities are lacking and providers depend on the materials provided by pharmaceutical companies. No facility received any SDG from national authorities, and providers must rely on their training and other resource materials. Providers indicated that, since their initial training on these commodities, they were able to dispense and administer them. Nurses sought support from doctors if they needed additional guidance. All visited facilities stored their drugs, including oxytocin, on shelves. Only MCWCs stored oxytocin in refrigerators.

Most drugs (especially injectable or intravenous infusions) are administered by physicians and trained service providers. Most providers have pre-service

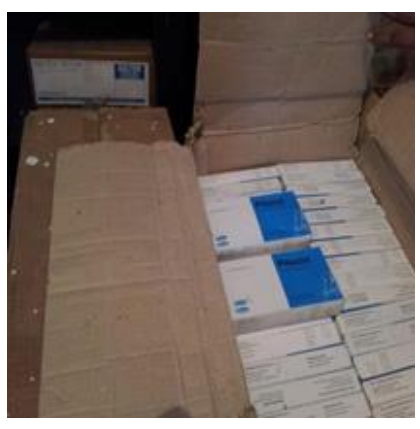

Oxytocin stored at room termnerature training and on-the-job training on clinical decision making and drug administration. The interviews revealed that, due to a lack of coordination between drug store keepers and providers, providers are unaware of which drugs and commodities are available in facility stores. Also, many providers reported an inability to estimate the consumption rate of drugs and commodities in their facilities because they lack data.

\section{Private pharmacies and drug stores}

Twenty-seven private drug stores and pharmacies were visited in August and September 2013 at district, sub-district, and community levels to determine drug and commodity availability. At all private drug stores, the most available drugs were amoxicillin, zinc, and ORS: All drug stores and pharmacies had these drugs stocked on the day of the visit.

TABLE 2: Maternal and neonatal health drugs and commodities available in private drug stores and pharmacies, by district

\begin{tabular}{|c|c|c|c|c|c|c|c|}
\hline \multirow{3}{*}{$\begin{array}{l}\text { Maternal and neonatal drug } \\
\text { or commodity }\end{array}$} & \multicolumn{6}{|c|}{ District } & \multirow{3}{*}{ Total (\%) } \\
\hline & \multicolumn{2}{|c|}{ Gazipur } & \multicolumn{2}{|c|}{ Zinaidah } & \multicolumn{2}{|c|}{ Comilla } & \\
\hline & $\begin{array}{l}\text { City/ } \\
\text { Sadar }\end{array}$ & Sub-district & $\begin{array}{l}\text { City/ } \\
\text { Sadar }\end{array}$ & Sub-district & $\begin{array}{l}\text { City/ } \\
\text { Sadar }\end{array}$ & $\begin{array}{l}\text { Sub- } \\
\text { district }\end{array}$ & \\
\hline Oxytocin for PPH & 4 & 0 & 5 & 5 & 3 & 2 & $19(70 \%)$ \\
\hline Misoprostol for PPH & 3 & 2 & 7 & 5 & 2 & 3 & $22(82 \%)$ \\
\hline $\begin{array}{l}\text { Magnesium sulphate }\left(\mathrm{MgSO}_{4}\right) \text { for severe } \\
\text { pre-eclampsia/eclampsia }\end{array}$ & 2 & 0 & 5 & 5 & 0 & 0 & $12(44 \%)$ \\
\hline Injectable antibiotics for newborn sepsis & 3 & 2 & 7 & 5 & 3 & 3 & $23(85 \%)$ \\
\hline Antenatal corticosteroids for PTRDS & $0^{25}$ & $0^{25}$ & $0^{25}$ & $0^{25}$ & $0^{25}$ & $0^{25}$ & $0(0 \%)^{25}$ \\
\hline Chlorhexidine for newborn cord care & $0^{25}$ & $0^{25}$ & $0^{25}$ & $0^{25}$ & $0^{25}$ & $0^{25}$ & $0(0 \%)^{25}$ \\
\hline $\begin{array}{l}\text { Resuscitation devices for newborn } \\
\text { asphyxia }\end{array}$ & $0^{26}$ & $0^{26}$ & $0^{26}$ & $0^{26}$ & $0^{26}$ & $0^{26}$ & $0(0 \%)^{26}$ \\
\hline Amoxicillin for pneumonia & 6 & 3 & 7 & 5 & 3 & 3 & $27(100 \%)$ \\
\hline ORS for diarrhea & 6 & 3 & 7 & 5 & 3 & 3 & $27(100 \%)$ \\
\hline Zinc for diarrhea & 6 & 3 & 7 & 5 & 3 & 3 & $27(100 \%)$ \\
\hline Female condom & $0^{26}$ & $0^{26}$ & $0^{26}$ & $0^{26}$ & $0^{26}$ & $0^{26}$ & $0(0 \%)^{26}$ \\
\hline Contraceptive implants & $0^{27}$ & $0^{27}$ & $0^{27}$ & $0^{27}$ & $0^{27}$ & $0^{27}$ & $0(0 \%)^{27}$ \\
\hline Emergency contraceptive pill & 1 & 1 & 5 & 5 & 3 & 2 & $17(63 \%)$ \\
\hline $\mathbf{N}$ & 6 & 3 & 7 & 5 & 3 & 3 & 27 \\
\hline
\end{tabular}

25 They sell different dose forms

26 Not available

27 Not authorized to sell

14 


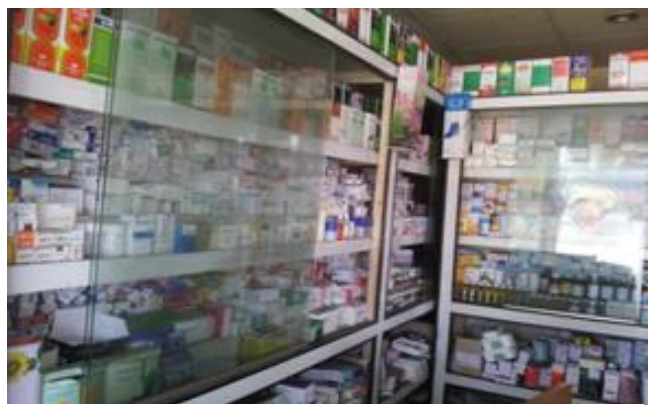

Private drug store

Other drugs such as oxytocin, misoprostol, and $\mathrm{MgSO}_{4}$ were less available. Almost all drug sellers report low demand for Oxytocin, Misoprostol, and $\mathrm{MgSO}_{4}$ and that the drugs require a doctor's prescription, making their sales volumes dependent on the extent to which doctors prescribe them. Drug store keepers explained that they lose money if drugs expire while on their shelves due to slow sales, and thus they do not stock them. In 15 percent of drug stores, injectable antibiotics were not found at the day of the visit. Similarly, ECPs were not found in 37 percent of drug stores. This pattern of unavailability was similar for all city or Sadar, subdistrict, and community levels. No seasonal variations were observed except for SMC ORSaline-N: Most drug sellers indicated that the demand for Social Marketing Company's ORSaline-N peaks in summer and quickly goes off the market due to increased demand. ORS produced by other companies are available in all seasons. Dexamethasone and betamethasone and chlorhexidine are available in all drug stores, but in different dose forms and unsuitable for pre-term respiratory distress syndrome and newborn cord care, respectively. Resuscitation devices and female condoms were not available in any of drug stores. MoHFW policy does not allow private drug stores to sell contraceptive implants.

A substantial price difference was observed for all drugs according to place of manufacture, whether in Bangladesh or overseas. Drugs manufactured overseas or by foreign companies in Bangladesh are more expensive than those produced locally, while no significant differences in prices were observed among dugs manufactured in Bangladesh. According to drug sellers, the price of most drugs (except injectable antibiotics) was affordable to end users. Drug sellers were unable to rate the quality of their different products and rely on the opinions of prescribing physicians.

Maintenance of a cold chain of storage for oxytocin's stability is crucial, yet two out of nine drug stores in Gazipur district, six out of 12 in Zinaidah district, and one out of six in Comilla district stored oxytocin on shelves rather than in the refrigerators. No drug seller had a refrigerator on the premises. All other drugs were stored on shelves at room temperature as well.

\section{LOGISTICS AND SUPPLY ORDERING}

Interviews with policymakers and program managers reveal that centralized and decentralized procurement processes for commodities and logistics each exist within MoHFW. MoHFW follows the World Bank procedure for procuring drugs and commodities, through an open bidding process, whereby the lowest bidder is awarded the supply contract if they have the requisite qualifications and fulfill the specifications in the tender.

Procurement is by two separate MoHFW systems. In the public

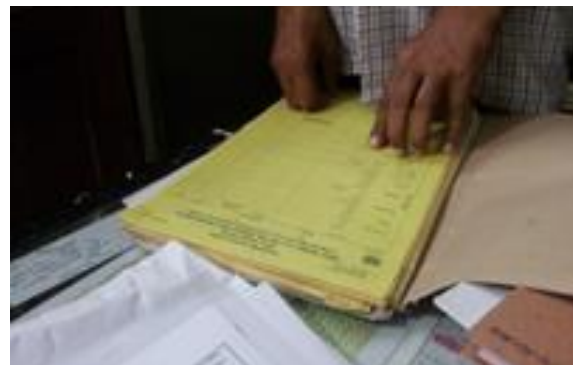

Register and reporting form health sector, most procurement is by the Centre for Medical Store Depot, at the central level, with a few items purchased at district levels. Drugs purchased at the district level are directed by a committee of the Civil Surgeon, Resident Medical Officer, Gynecological and Obstretics Consultant, and Surgery Consultant that estimates purchase volumes based on the previous year's utilization of the individual product. Usually, however, drugs and commodities are ordered at the national level, stored at the central warehouse, and then distributed to districts and facilities. There is no scope for local procurement, at the sub-district level, for health departments. All drugs and commodities are forecasted at the central level according to the lower level facilities' requests for each commodity.

The FP sector has an extensive process for procurement and logistics. Typically, a Director executes a need assessment of drugs and commodities based on utilization rates, includes it in the appropriate year's procurement plan, and the information is loaded to the MoHFW web portal. The Ministry provides approval for procurement and DGFP issues the tender, with a tender evaluation committee (with the Director General, 
Director of Logistics and Procurement, the respective Director, and two members from the other two ministries) evaluating the subsequent proposals and ranking them on their technical and financial aspects.

The central warehouse mainly procures DDS Kits (Appendix 3), misoprostol, oxytocin, and contraceptives with the exception of ECPs. A quality control team verifies and certifies the quality of each drug and commodity according to the supply order, after which payment is made. Distribution is usually according to forms $7^{28}$ and $7 \mathrm{~b}^{29}$ and calculated for estimated consumption in the coming three months. Each facility then receives their allocated number of DDS Kits containing 26 drugs and commodities per kit. Contraceptive forecasting and procurement occur at the central level, with storage is at the central warehouse, followed by distribution to regional warehouses and then to upazila stores, from which facilities and workers collect commodities. In all facilities including warehouses, at least one month's supply of drugs and commodities are mandated, unless there is a central shortage of a supply. Contraception and DDS Kit distribution is usually in accordance with the 'push' method, permanent methods are procured 'on demand' by facilities. All facilities record supply and use of drugs and commodities in registers. DGFP's LMIS system tracks the 13 UN commodities. SIAPS is working with DGHS to develop a similar system.

Private and NGO clinics have their own systems for commodity purchase and supply according to their needs. Private and NGO clinics can collect contraceptives from their local authorities and, if registered with the FP department, can provide FP services.

Most respondents in facilities were unaware of the national quality control guidelines and assurances. Respondents from pharmaceutical companies did, however, mention that DGDA quality control guidelines require them to have their own Standard Operating Procedures (SOPs) and ISO certifications. Service providers in facilities mentioned that end users are not willing to pay for drugs and commodities. In addition, they also mentioned low demand for oxytocin, misoprostol, $\mathrm{MgSO}_{4}$, ANCS, zinc, and ECP.

\section{MANUFACTURING AND DISTRIBUTION}

Several domestic pharmaceutical manufacturers produce most of the 13 life-saving commodities; resuscitation devices, contraceptive implants, and female condoms are the only products not manufactured locally. In this study two manufacturers were visited, and relevant persons interviewed. The two companies visitied manufacture most of the listed drugs and commodities available in Bangladesh (Table 3b). Drugs and commodities manufactured by local pharmaceutical companies are available at www.bddrugs.com. Contraceptive implants (Implanon) are imported from Organon, MSD, and Netherland, and are distributed by Janata Traders.

Resuscitation devices were donated by USAID through the Helping Babies Breathe program. Many companies do not manufacture hormonal preparations such as contraceptive pills or injectables-only one pharmaceutical company manufactures injectable contraceptives-but at least four companies produce ECPs. No pharmaceutical company produces Chlorhexidine and antenatal corticosteroids in appropriate dose forms, although they have preparations in different dose forms for other indications. Only four local companies (Table $3 b$ ) manufacture and market oxytocin, as its need for cold chain production and storage require more specialized resources and skills.

The prices of local products are regulated by DGDA. Without DGDA approval no pharmaceutical company can set a price for their drugs or commodities. Companies adhere to drug policy rules and regulations when setting their prices, which results in no excessive pricing differences for drugs produced by various domestic companies; drugs manufactured by foreign companies do not adhere to those pricing guidelines.

Pharmaceutical companies generally teach storage practices to drug distributors but not to drug stores themselves, which has resulted in difficient knowledge of correct product storage. Although there is no visible public-private partnership in pharmaceutical production, DGDA has expressed an interest in such efforts.

\footnotetext{
28 Monthly issue, distribution and balanced sheet, central and regional warehouse

29 Upazila monthly supply, distribution and stock balance report 


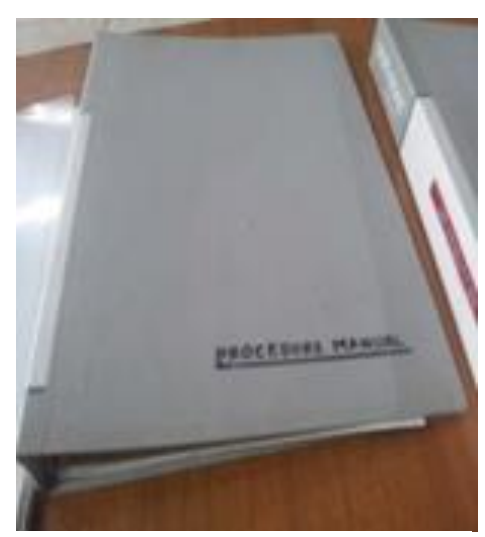

Pharmaceutical company Procedure Manual

\section{QUALITY CONTROL AND ASSURANCE}

Bangladesh's National Drug Policy requires each pharmaceutical company to have quality control (QC) and quality assurance (QA) systems for monitoring their entire manufacturing process, from acquisition of raw materials through completion to finished product. It also requires all pharmaceutical companies to have documented Standard Operating Procedures (SOPs) based on WHO-recommended current Good Manufacturing Practice guidelines for each product and unit process. These SOPs can include quality control laboratories or access to licensed medicine manufacturing facilities, equipment, qualified personnel, procedures, and references ${ }^{30,31}$.

As part of the quality control program, the Bangladesh government established two drug testing laboratories in Dhaka and Chittagong districts. Findings from the interviews with drug authorities and pharmaceutical representatives reveal that these drug testing laboratories' capacities are limited both in terms of manpower and logistics: They can only can test about 30 percent of Bangladesh's 3,500 total products each year.

Every medicine available for consumption must qualify its approved standards (specifications). The standard for a medicine should be indicated in the application meaning which pharmacopoeia they would follow (e.g. British Pharmacopoeia (BP), International Pharmacopeia (IP), United States Pharmacopoeia (USP), and European Pharmacopoeia (EPh), etc.). Recently, DGDA approved the National Pharmacopoeia, which was also approved by WHO.

As the government has limited capacity to control the quality of all drugs, it is primarily a manufacturer's responsibility to ensure quality, but DGDA is the National Regulatory Authority and is ultimately responsible for the regulation and quality assurance of all medicines. Initially, licensed manufacturers develop formulations and prepare samples of a medicine on trial and error basis in their own laboratory and test the samples following specifications of established Pharmacopoeia. They need to validate their test procedures and submit the samples to DGDA for testing and analysis in the Government Drug Testing Laboratory for registration with a certificate from their own test. The submitted samples must comply with their standard specification and passed by the Government Analyst ${ }^{32}$.

Before confirming registration of a new product, DGDA sends a team of inspectors to assess the pharmaceutical company's manufacturing facility, including their drug testing laboratories. Per public drug rules, DGDA inspects every manufacturing unit during renewal of their drug manufacturing licenses (every two years). DGDA also monitors the quality of marketed drugs by collecting samples at random from different drugstores and medicine markets and tests those drug samples in government laboratories. For imported medicines all distributors should have Free Sale Certificates of the National Regulatory Authority of at least one of the seven developed countries (UK, USA, Germany, France, Switzerland, Australia and Japan) or Good Manufacturing Practice (GMP) certificate from WHO. This procedure is followed to ensure the safety, quality, and effectiveness of the imported drug ${ }^{32}$.

If any drug sample is declared substandard by the government analyst then the production, distribution and marketing of the respective batch of the drug is immediately suspended and instructions issued to the manufacturer to withdraw the batch from all channels by publishing withdrawal notices in at least two widely circulated daily newspapers. Simultaneously, investigations by DGDA inspectors examine the root causes. DGDA also lodges a case in the Drug Court against the responsible persons of the drug manufacturer for punitive actions.

\footnotetext{
30 Drug Policy of the Government of Bangladesh, MoH\&FW

${ }^{31}$ Quality Manual of Directorate General of Drug Administration, Bangladesh, MoH\&FW

32 Quality Manual of Directorate General of Drug Administration, Bangladesh, MoH\&FW 


\section{PACKAGING}

Findings from the in-depth interviews indicate that separate packaging of all 13 commodities is not available. National workshop participants reiterated this fact. Many of the 13 commodities are provided in universal dose forms, and service providers must decide how much has to be given for specific MNH indications. Antibiotics for neonatal sepsis are available in various dose forms for drops, suspension, tablets, and injection, each in different concentrations not specifically packaged for neonatal sepsis, but which is simply mentioned as one of the indications on the packaging. Similarly, $\mathrm{MgSO}_{4}$ is available in solution and power for solution forms in different concentrations. There is no separate packaging for a loading dose of 10 $\mathrm{mg}$ in a vial. Current available forms are 2.46 grams per $5 \mathrm{ml}$ or 4 grams in per $100 \mathrm{ml}$ vial, which means that four vials are required as a loading dose in the community before referral.

All respondents in the national workshop, as well as most service providers, recommend a separate single dose packaging of these essential drugs. They suggest the same for a single dose of gentamycin for neonatal sepsis. The piloting of misoprostol for PPH prevention and treatment was conducted with separate packaging specifying the indication. The same procedure is due for scale up in 18 districts. The manufacturer was instructed to make separate packaging of $400 \mathrm{mcg}$ tablets (200 mcg x 2) for PPH prevention. Similarly, pharmaceutical companies are required to have separate package of misoprostol with mifepristone for the specific indication of medical termination of pregnancy, and it is now on the market. No drug is included in existing bundles such as the delivery kit but there are ongoing discussions about its inclusion. Separate packaging had enormous support from all respondents, who feel that separate packing of appropriate doses would greatly improve correct indications and doses.

\section{FINANCING}

It is government policy to supply all dugs and commodities (including FP commodities) free of cost to those securing services either at facilities or through doorstep delivery ${ }^{31}$. In reality, service and drugs from facilities are not free of cost, with clients encountering considerable out-of-pocket expenses. They frequently must purchase drugs from private drug stores due to supply shortages or pay informal service fees ${ }^{33}$.

Clients are charged for services within the private sector. NGOs charge subsidized rates. All interviewed respondents, workshop participants, and public facility service providers mentioned stated that end users are not willing to pay for drugs and commodities, and the ultra poor cannot pay for anything. Drug sellers, however, are of the opinion that, in terms of health expenditures and out-of-pocket expenses, the costs of MNH drugs and commodities on the open market are within most end users' reach. The respondents also mentioned that there must be a safety net provided for the ultra poor. All respondents also felt that products should be included in conditional cash transfer coupons, vouchers, or other similar schemes, particularly the ongoing public sector maternal health voucher schemes.

\section{ENGAGING POLICY MAKERS, PROGRAM MANAGERS, AND OTHER STAKEHOLDERS}

As an initial activity of this engagement, two meetings with DGFP explored how to roll out the UN Commission recommendations. This was a follow up activity after the validation workshop that recommended forming an advocacy forum to ensure maternal and neonatal health drug and commodities are a cause that is taken up by relevant stakeholders. It was requested that Population Council take the responsibility for developing Terms of Reference of the forum. DGFP's Director of Maternal and Child Health intends to call a bigger meeting and an effort is ongoing to create this advocacy forum.

\footnotetext{
${ }^{33}$ Rahman, L., U. Rob, R. Mahmud, A. Alim, I.A. Hena, M.N. Talukder and H. Rahman. 2012. A pay-for-performance innovation integrating the quantity and quality of care in maternal, newborn and child health services in Bangladesh. Dhaka: Population Council.
} 


\section{Challenges, Opportunities, Recommendations}

Interviews with policymakers, program managers, service providers, store keepers, drug sellers, and workshop participants revealed a number of challenges, opportunities, and recommendations:

\section{CHALLENGES}

- Shortages of all essential drugs and commodities in public health facilities;

- Inappropriate storage of oxytocin (and consequential use of an ineffective drug during crucial medical events) is widespread;

- Unavailability of antenatal corticosteroids in correct dose forms (6 mg injection) for pre-term respiratory distress syndrome; unavailability of Chlorhexidine in correct concentration (7.1\%) for newborn cord care; provider use of inappropriate concentration; and lack of SDGs;

- Unavailability of Magnesium Sulfate in appropriate dose forms and need for manufacturing a single loading dose for severe pre-eclampsia or eclampsia, and lack of interest from pharmaceutical companies;

- Lack of advocacy with pharmaceutical companies for manufacturing less profitable but essential drugs in appropriate dose forms;

- Lack of awareness of Emergency Contraceptive Pills due to lack of educational efforts;

- Lack of knowledge and low use of zinc sulphate for neonatal diarrhea;

- Absence of a forum at DGFP that advocates for mothers and ensures access to and use of essential maternal health drugs and commodities.

\section{OPPORTUNITIES}

- All 13 drugs and commodities are registered (except the female condom) are registered in the country in different dose forms, meaning that registration for different, altered dose forms is feasible.

- The Directorate General of Drug Administration is very much in favor of ensuring the availability, quality, and affordability of essential maternal and neonatal health drugs and commodities. They requested an application for the approval of essential drugs in required dose forms. DGFP was requested to form an advocacy forum to ensure the availability of maternal health drug and commodities. Systems for Improved Access to Pharmaceuticals and Services (SIAPS) supported a Forecasting Working Group at DGFP. DGHS has a Supply Chain Coordination Forum where UN, WB, UNAIDS, MoHFW, and other stakeholders are partnered.

- Chlorhexidine has already been approved by the Directorate General of Drug Administration in appropriate concentration, and DGHS's National Core Committee for Neonatal Health and DGFP's National Technical Committee approved its use in the vertical program. Social Marketing Company has reportedly began manufacture the drug, and Save the Children is piloting its use in one district.

- DGHS's National Core Committee for Neonatal Health and DGFP's National Technical Committee have approved introduction and scale up of dexamethasone sodium sulphate $6 \mathrm{mg}$ intramuscular injection for pre-term respiratory distress syndrome, for use both in facilities and within communities.

- The Directorate General of Drug Administration issued letter for appropriate storage of oxytocin in all public health facilities, and DGHS and DGFP have also issued letter to all facilities.

- Systems for Improved Access to Pharmaceuticals and Services (SIAPS) and other stakeholders are facilitating DGHS's and DGFP's quantification of the MNH commodities needed for facilities. DGFP has an LMIS system for tracking the 13 UN commodities. They have also proposed including Chlorhexidine and misoprostol in standard infant delivery kits. 
- Participating respondents are concerned about the unavailability and inappropriate dose forms of MNH commodities, suggesting a wide basis of support for improved commodity availability.

- The participating respondents are concerned about the use of low dose misoprostol for PPH prevention and treatment.

- Social Marketing Company and Mayer Hashi of EngenderHealth initiated training for implant insertion and removal through private providers.

\section{RECOMMENDATIONS}

\section{Maternal health}

- Misoprostol should be bundle with birthing delivery kits.

- Advocacy with pharmaceutical companies should to manufacture a single loading dose of $\mathrm{MgSO}_{4}$ solution.

- Participants have suggested assessing the effectiveness of $400 \mathrm{mcg}$ versus $600 \mathrm{mcg}$ misoprostol in preventing post-partum hemorrhage in the Bangladeshi context.

- Essential drugs and commodities for mother should be made available in Union Health and Family Welfare Centers where normal vaginal deliveries are planned and conducted.

\section{Neonatal health}

- Chlorhexidine should be bundled with birthing delivery kits.

- Resuscitation devices should be available in all districts, particularly in all facilities where deliveries are conducted.

- Advocacy should be conducted with pharmaceutical companies to manufacture single dose of gentamycin injection and $7.1 \%$ Chlorhexidine.

- Essential drugs and commodities for neonate should be made available in UH\&FWCs where normal vaginal deliveries are planned and conducted.

- Single dose injectable antibiotics should be manufactured and promoted for neonatal sepsis.

- Educational efforts should be strengthened toward in increasing awareness of zinc use in diarrheal diseases.

\section{Family Planning commodities}

- DGFP should take initiatives to increase public awareness of avoiding unplanned pregnancy and ensure availability of ECPs in all facilities as well as to fieldworkers.

\section{General recommendations}

- Formation of a forum at DGFP to advocate ensuring access to and use of MNH drugs and commodities.

- Further initiatives are necessary to ensure drug quality, appropriateness of dosage, and reliable availability in both the private and public spheres.

- Directorate General of Drug Administration, DGFP, and DGHS should be regularly updated by active stakeholders on the global updates on maternal and neonatal health and other public health issues. 
Table 3a: Policy, guidelines, and availability matrix of 13 life-saving maternal and neonatal health commodities in Bangladesh

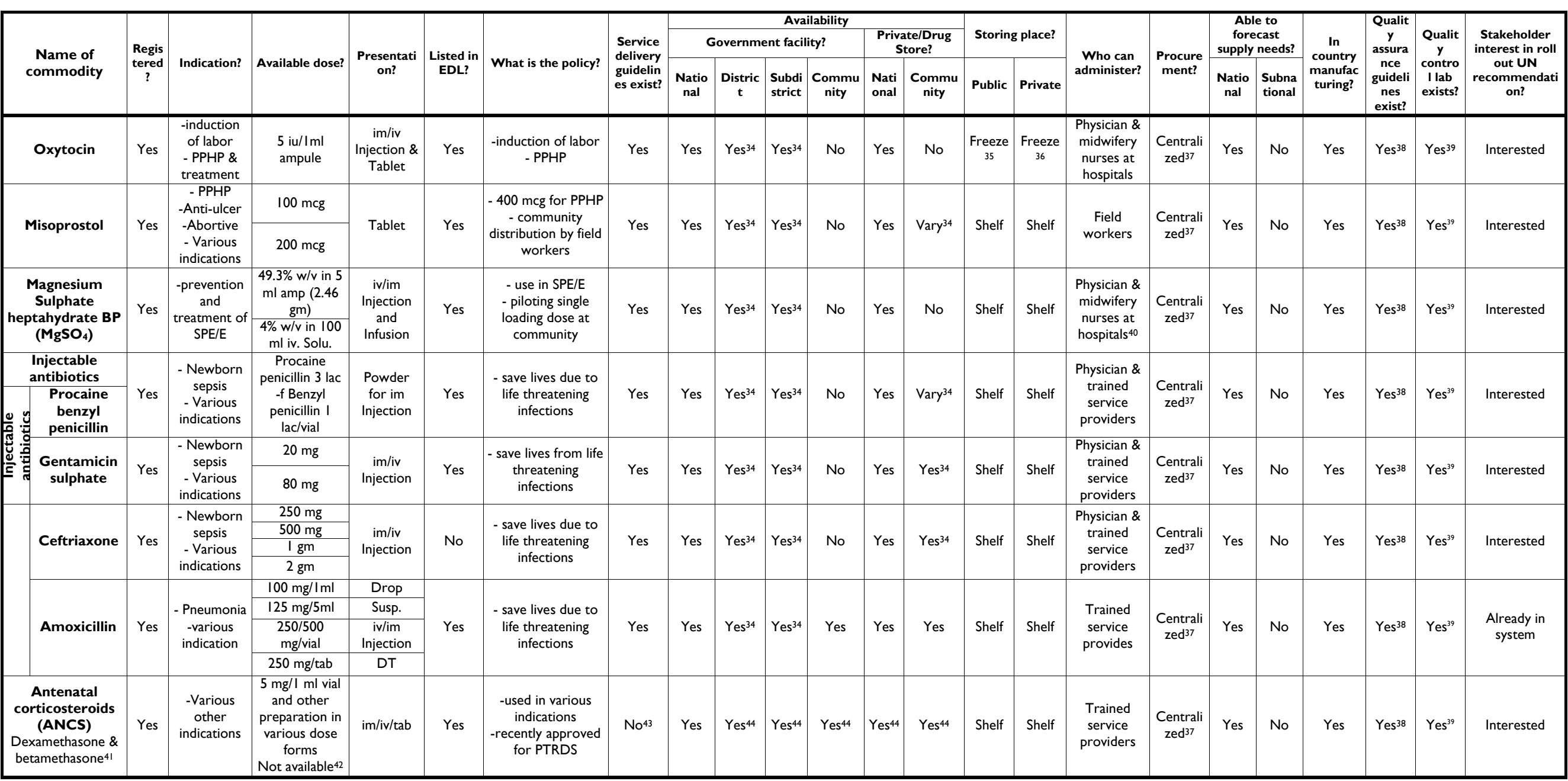

${ }^{34}$ Some places it is available and some places not.

35 most places they kept it in the shelf in normal temperature.

${ }_{7}^{3}$ In mostral temperature and found in shelf.

${ }_{38}$ Companies follow the QA guidelines of that pharmac can purchase it from the local market from available fund.

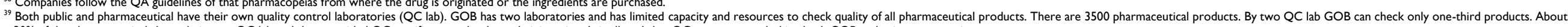
${ }_{40} 30 \%$ of the pharmaceuticals have their own QC lab and they provided QC certificate to the drug administration. It is alleged that QC measures are lacking both GOB and private companies.

${ }_{4}^{40}$ Trial is being conducted to administer loading dose of $\mathrm{MgSO}_{4}$ through community based facility level service providers

${ }_{42}$ Available dose is $5 \mathrm{mg} / \mathrm{Iml}$ iv or im injection

${ }^{43}$ Available dose is $5 \mathrm{mg} / \mathrm{lml}$ are intended for various other reasons not for PTRDS. PTRDS needs $6 \mathrm{mg}$ im/iv dose that is not available. SDGs are being prepared.

${ }^{44}$ Available but not in appropriate dose form. Not in injection form. 


\begin{tabular}{|c|c|c|c|c|c|c|c|c|c|c|c|c|c|c|c|c|c|c|c|c|c|c|c|}
\hline \multirow{3}{*}{$\begin{array}{c}\text { Name of } \\
\text { commodity }\end{array}$} & \multirow{3}{*}{$\begin{array}{c}\text { Regis } \\
\text { tered } \\
?\end{array}$} & \multirow{3}{*}{ Indication? } & \multirow{3}{*}{ Available dose? } & \multirow{3}{*}{$\begin{array}{l}\text { Presentati } \\
\text { on? }\end{array}$} & \multirow{3}{*}{$\begin{array}{c}\text { Listed in } \\
\text { EDL? }\end{array}$} & \multirow{3}{*}{ What is the policy? } & \multirow{3}{*}{\begin{tabular}{|l} 
Service \\
delivery \\
guidelin \\
es exist?
\end{tabular}} & \multirow{2}{*}{\multicolumn{4}{|c|}{$\begin{array}{r}\text { Availability } \\
\text { Government facility? }\end{array}$}} & \multirow{2}{*}{\multicolumn{2}{|c|}{$\begin{array}{l}\text { Private/Drug } \\
\text { Store? }\end{array}$}} & \multirow{2}{*}{\multicolumn{2}{|c|}{ Storing place? }} & \multirow{3}{*}{$\begin{array}{c}\text { Who can } \\
\text { administer? }\end{array}$} & \multirow{3}{*}{$\begin{array}{l}\text { Procure } \\
\text { ment? }\end{array}$} & \multirow{2}{*}{\multicolumn{2}{|c|}{\begin{tabular}{|c|}
$\begin{array}{c}\text { Able to } \\
\text { forecast } \\
\text { supply needs? }\end{array}$ \\
\end{tabular}}} & \multirow{3}{*}{\begin{tabular}{|c} 
In \\
country \\
manufac \\
turing?
\end{tabular}} & \multirow{3}{*}{\begin{tabular}{|c|} 
Qualit \\
$y$ \\
assura \\
nce \\
guideli \\
nes \\
exist? \\
\end{tabular}} & \multirow{3}{*}{$\begin{array}{c}\text { Qualit } \\
y \\
\text { y } \\
\text { contro } \\
\text { I lab } \\
\text { exists? }\end{array}$} & \multirow{3}{*}{$\begin{array}{c}\text { Stakeholder } \\
\text { interest in roll } \\
\text { out UN } \\
\text { recommendat } \\
\text { on? }\end{array}$} \\
\hline & & & & & & & & & & & & & & & & & & & & & & & \\
\hline & & & & & & & & $\begin{array}{c}\text { Natio } \\
\text { nal }\end{array}$ & 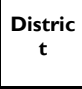 & $\begin{array}{l}\text { Subdi } \\
\text { strict }\end{array}$ & $\underset{\text { nity }}{\text { Commu }}$ & $\begin{array}{l}\text { Nati } \\
\text { onal }\end{array}$ & $\begin{array}{c}\text { Commu } \\
\text { nity }\end{array}$ & Public & Private & & & $\begin{array}{c}\text { Natio } \\
\text { nal }\end{array}$ & $\begin{array}{l}\text { Subna } \\
\text { tional }\end{array}$ & & & & \\
\hline digluconate & No & $\begin{array}{l}\text { - Neonatal } \\
\text { umbilical } \\
\text { cord care }\end{array}$ & $\begin{array}{l}7.1 \% \text { not } \\
\text { available }\end{array}$ & - & No & $\begin{array}{l}\text {-recently approved } \\
\text { for newborn cord } \\
\text { care at facility and } \\
\text { community } \\
\text {-single use during } \\
\text { umbilical cord } \\
\text { stamp followed by } \\
\text { dry cord care }\end{array}$ & No45 & No & No & No & No & No & No & - & - & $\begin{array}{l}\text { Trained } \\
\text { service } \\
\text { providers }\end{array}$ & - & Yes & No & Planned & - & Yes $^{39}$ & Interested \\
\hline \multirow{5}{*}{ gluconate } & \multirow{5}{*}{ Yes $^{46}$} & $\begin{array}{c}\text { Vaginal } \\
\text { cleansing }\end{array}$ & $0.16 \%-0.60 \%$ & Solution & \multirow{5}{*}{ Yes } & \multirow{5}{*}{$\begin{array}{c}\text { - reduce bacterial } \\
\text { infection in various } \\
\text { situation } \\
\text {-over the counter }\end{array}$} & \multirow{5}{*}{ Yes } & \multirow{5}{*}{ Yes } & \multirow{5}{*}{ Yes } & \multirow{5}{*}{ Yes } & \multirow{5}{*}{ Yes } & \multirow{5}{*}{ Yes } & \multirow{5}{*}{ Yes } & & & & & & & & & & \\
\hline & & $\begin{array}{c}\text { Neonatal } \\
\text { skin wiping }\end{array}$ & $0.16 \%-0.60 \%$ & $\begin{array}{l}\text { Solution, } \\
\text { Hand rub }\end{array}$ & & & & & & & & & & & & & & & & & & & \\
\hline & & Eyewash & $.05 \%$ & Solution & & & & & & & & & & Shelf & Shelf & service & $\begin{array}{l}\text { Centrali } \\
\text { zed }^{37}\end{array}$ & Yes & No & Yes & Yes & Yes $^{39}$ & - \\
\hline & & Dental wash & $0.12 \%-1 \%$ & Solu, gel & & & & & & & & & & & & & & & & & & & \\
\hline & & $\begin{array}{l}\text { Preoper. } \\
\text { skin } \\
\text { cleansing }\end{array}$ & $2.0 \%$ & Solution & & & & & & & & & & & & & & & & & & & \\
\hline $\begin{array}{l}\text { Resuscitation } \\
\text { devices }\end{array}$ & Yes & $\begin{array}{l}\text { - Newborn } \\
\text { asphyxia }\end{array}$ & $\begin{array}{c}240 \mathrm{ml} / 500 \mathrm{ml} \\
\text { size volume, } \\
\text { specifically } \\
\text { designed }\end{array}$ & $\begin{array}{c}\text { Self- } \\
\text { inflating } \\
\text { bag, mask } \\
\text { \& suction } \\
\text { devices }\end{array}$ & No & $\begin{array}{l}\text {-manage newborn } \\
\text { asphyxia }\end{array}$ & Yes & Yes & $Y_{e s}{ }^{77}$ & Yes ${ }^{47}$ & No47 & Yes & No & Shelf & Shelf & $\begin{array}{l}\text { Trained } \\
\text { service } \\
\text { providers }\end{array}$ & Donated & Yes & No & No & No & No & Interested \\
\hline ORS 48 & Yes & - Diarrhea & $\begin{array}{c}\text { Nacl I.30 gm; } \\
\text { Kcl } 0.75 \mathrm{gm} ; \\
\text { Tri Sodium } \\
\text { Citrate, Dye } \\
\text { Hydrate I.45 } \\
\text { gm; Glucose, } \\
\text { Anhydrous } \\
6.75 \mathrm{gm}^{49}\end{array}$ & Sachet & Yes & $\begin{array}{l}\text {-rehydration } \\
\text { therapy for } \\
\text { diarrhea } \\
\text { - over the counter }\end{array}$ & Yes & Yes & Yes & Yes & Yes & Yes & Yes & Shelf & Shelf & $\begin{array}{l}\text { Over the } \\
\text { counter } \\
\text { product }\end{array}$ & $\begin{array}{l}\text { Centrali } \\
\text { zed }^{37}\end{array}$ & Yes & No & Yes & Yes $^{38}$ & Yes $^{39}$ & $\begin{array}{l}\text { Already in } \\
\text { system }\end{array}$ \\
\hline Zinc $^{50}$ & Yes & - Diarrhea & \begin{tabular}{|c|} 
Zinc sulphate \\
monohydrate \\
$10 \mathrm{mg} / 20 \mathrm{mg} / 5$ \\
$\mathrm{ml} / \mathrm{tab} / \mathrm{syrup}$ \\
\end{tabular} & $\begin{array}{l}\text { Tablet } \\
\text { Syrup }\end{array}$ & Yes & $\begin{array}{l}\text {-prevent diarrhea } \\
\text {-feed for } 10 \text { days } \\
\text { - over the counter }\end{array}$ & Yes & Yes & Yes & Yes & Yes & Yes & Yes & Shelf & Shelf & $\begin{array}{l}\text { Over the } \\
\text { counter } \\
\text { product }\end{array}$ & $\begin{array}{l}\text { Centrali } \\
\text { zed }^{37}\end{array}$ & Yes & No & Yes & Yes $^{38}$ & Yes $^{39}$ & $\begin{array}{l}\text { Already in } \\
\text { system }\end{array}$ \\
\hline Female condom & No & - & - & - & - & Not interested & & - & - & - & - & - & - & - & - & - & - & - & - & - & - & - & - \\
\hline $\begin{array}{c}\text { Contraceptive } \\
\text { implants } \\
\text { (implanon/ Jadelle) }\end{array}$ & Yes & $\begin{array}{c}\text {-long-term } \\
\text { (3-5 yrs) } \\
\text { female } \\
\text { contraceptio } \\
n\end{array}$ & \begin{tabular}{|c|}
$\begin{array}{c}68 \mathrm{mg} \\
\text { etonogestrel }\end{array}$ \\
$75 \mathrm{mg}$ \\
levonorgestrel
\end{tabular} & Two rods & $\begin{array}{c}\text { In the } \\
\text { method } \\
\text { mix }\end{array}$ & $\begin{array}{c}\text {-On-demand } \\
\text {-Available at } \\
\text { designated facility } \\
\text {-any woman eligible } \\
\text { even nulliparous }\end{array}$ & Yes & Yes & Yes & Yes & $\mathrm{No}^{51}$ & $\mathrm{No}^{52}$ & No & Shelf & Shelf & $\begin{array}{c}\text { Only trained } \\
\text { Physician }\end{array}$ & $\begin{array}{c}\text { Centrali } \\
\text { zed }\end{array}$ & Yes & No & No & No & No & $\begin{array}{l}\text { Already in } \\
\text { system }\end{array}$ \\
\hline $\begin{array}{l}\text { Emergency } \\
\text { contraception }\end{array}$ & Yes & $\begin{array}{c}\text {-Back-up } \\
\text { contraceptio } \\
n\end{array}$ & $\begin{array}{c}0.75 \mathrm{mg} / 1.5 \\
\mathrm{mg} / \text { tab } \\
\text { Levonorgestrel }\end{array}$ & Tablet & \begin{tabular}{|} 
DGFP \\
method \\
mix
\end{tabular} & $\begin{array}{c}\text { - over the counter } \\
\text {-single dose within } \\
5 \text { days of } \\
\text { unprotected sex }\end{array}$ & Yes & Yes & Yes $^{53}$ & Yes $^{53}$ & Yes $^{53}$ & Yes & Yes & Shelf & Shelf & $\begin{array}{l}\text { Over the } \\
\text { counter } \\
\text { product }\end{array}$ & $\begin{array}{l}\text { Centrali } \\
\text { zed }\end{array}$ & Yes & No & Yes & Yes $^{38}$ & Yes $^{39}$ & $\begin{array}{l}\text { Already in } \\
\text { system }\end{array}$ \\
\hline
\end{tabular}

${ }_{46}^{45}$ One piloting is being conducted and working with MOH for the preparation and guidelines for the required concentration (7.1\% chlorhexidine digluconate for cord cleansing).

${ }^{46}$ The ingredient is registered but the concentration required for newborn cord care is not available or registered. Various concentration and combination is available. They are all Chlorhexidine gluconate and hydrochloride not Chlorhexidine digluconate. ${ }_{48}^{47}$ Only in district where HBB program was implemented. In most of the places it is not available.

${ }^{48}$ Also available with supplements

${ }^{50}$ Also available with supplements

${ }^{52}$ In a very few places it available with NGO initiatives. where primary level facilities are upgraded or camps are being organized.

53 Policy is there to make it available but there is lack of supply. 
Table 3b: Availability matrix of 13 life-saving maternal and neonatal health commodities in Bangladesh, by pharmaceutical companies, market retail price, available packaging, and willingness to pay by end users

\begin{tabular}{|c|c|c|c|c|c|c|c|}
\hline & Name of commodity & Name of pharmaceutical companies who manufacture it & Brand names & Available dose? & Market prices? & \begin{tabular}{|c|c|} 
Separate \\
packaging?
\end{tabular} & $\begin{array}{l}\text { WTP by } \\
\text { end-user? }\end{array}$ \\
\hline & Oxytocin & $\begin{array}{l}\text { Nuvista Phar. Ltd., Opsonin Phar. Ltd., Chemist Laboratories Ltd., Techno } \\
\text { Drugs }\end{array}$ & Linda-S, Ocin, Pitocin, Syntocin & $5 \mathrm{iu} / \mathrm{Iml}$ ampule & Tk. ${ }^{54} 8-11 / a m p$ & No & Yes $^{55}$ \\
\hline & Misoprostol $^{56}$ & Incepta Phar. Ltd., Gonoshasthaya Phar. Ltd., Square Phar. Ltd. & Cytomis, G-Misoprostol, Isovent & $\frac{100 \mathrm{mcg}}{200 \mathrm{mcg}}$ & $\begin{array}{c}\text { Tk..8/tab } \\
\text { Tk.10-15/tab }\end{array}$ & $\mathrm{Yes}^{57}$ & Yes $^{55}$ \\
\hline & um Sulphate heptahydrate BP & Opsonin Phar. Ltd, Gonoshasthaya Phar. Ltd (GPL), Renata Ltd, Gonoshasthaya Phar. & $\begin{array}{l}\text { Eclamsil 49.3\%, G-Magsulph 49.3\%, } \\
\text { Magsum 49.3\% }\end{array}$ & $\begin{array}{c}49.3 \% \mathrm{w} / \mathrm{v} \text { in } 5 \mathrm{ml} \text { amp }(2.46 \\
\mathrm{gm})\end{array}$ & Tk. $20-25 / 5 \mathrm{ml} \mathrm{amp}$ & $\mathrm{No}$ & Yec55 \\
\hline & $\left(\mathrm{MgSO}_{4}\right)$ & Ltd (GPL), Beximco Phar. Ltd. & G-Magsulph 4\%, Nalepsin 4\% & $4 \% \mathrm{w} / \mathrm{v}$ in $100 \mathrm{ml}$ iv. solution & $\begin{array}{l}\text { Tk. } 55-71 / 100 \mathrm{ml} \\
\text { bot. }\end{array}$ & 100 & ( \\
\hline & Injectable antibiotics & & & (Procaine penicillin 3 lac -f & & & \\
\hline & & ACME Laboratories Ltd, Renata Ltd & Combipen 4 Lac, Pronapen 4 Lac & $\begin{array}{l}\text { Benzyl penicillin I lac/vial) } \\
\quad(I \mathrm{~g}=1 \mathrm{mill} \text { lion IU) } \\
(50 \mathrm{mg} / \mathrm{kg} \mathrm{IM})\end{array}$ & Tk. 6-10/vial & No & Yes $^{55}$ \\
\hline 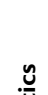 & Procaine benzyl penicillin & & Pronapen 8 Lac & $\begin{array}{c}\text { Procaine penicillin } 6 \text { lac, } \\
\text { Benzyl penicillin } 2 \text { lac (total } 8 \\
\text { lac) in I vial }\end{array}$ & Tk. 10/vial & & \\
\hline 茄 & & & Egen, Genacyn, Genacyn, Gentabac, & $20 \mathrm{mg}$ & Tk. 6-7/2 ml amp & & \\
\hline 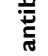 & $\begin{array}{l}\text { Gentamicin } \\
\text { sulphate }\end{array}$ & $\begin{array}{l}\text { Edruc Ltd, Square Phar. Ltd., Square Phar. Ltd., Popular Phar. Ltd., Techno Drugs, } \\
\text { Opsonin Phar. Ltd, GPL, Incepta Phar. Ltd., Beximco Phar. Ltd., Aristopharma Ltd. }\end{array}$ & $\begin{array}{l}\text { Gentasol, Gentin, G-Gentamicin, } \\
\text { Intamycin, Invigen }\end{array}$ & $80 \mathrm{mg}$ & $\begin{array}{l}\text { Tk. } 9.50-12 / 2 \mathrm{ml} \\
\text { amp }\end{array}$ & No & Yes ${ }^{55}$ \\
\hline$\cong$ & & & & $80 \mathrm{mg}$ iv infusion & Tk. $48 / 100 \mathrm{ml}$ vial & & \\
\hline है & & Renata Ltd., Techno Drugs, IBN SINA Phar. Industry Ltd., Aristopharma Ltd., Beximco & Ceftizone, Cefixon, Axosin, Axon, Arixon, & 250 mg iv/im & Tk. 75-I30/vial & & \\
\hline$\stackrel{\mathscr{u}}{=}$ & & $\begin{array}{l}\text { Phar. Ltd., ACI Ltd, Novo Healthcare and Phar. Ltd., Square Phar. Ltd., Drug } \\
\text { International Ltd.. Sanofi-aventis (Bd) Ltd., Popular Phar. Ltd., Incepta Phar. Ltd., GPL. }\end{array}$ & Aciphin, Ceftrix, Ceftron, Dicephin, & $500 \mathrm{mg}$ iv/im & Tk. 120-145/vial & & \\
\hline & Coftriarone $\mathrm{c}$ & General Phar. Ltd., Rephco Laboratories Ltd., Apex Phar. Ltd., Sandoz/Novartis (Bd) & Enocef, Eracef, Exephin, G-Ceftriax, & I gm iv/im & Tk. 160-195/vial & & \\
\hline & Ceftriaxone & Ltd., Healthcare Phar. Ltd, Rangs Phar. Ltd., Jayson Phar. Ltd., Kemiko Phar. Ltd., & Imacef, Inoxon, Keptrk, Megion, Oricef, & $2 \mathrm{gm} \mathrm{iv} / \mathrm{im}$ & Tk. 250-350/vial & No & Yes $^{55}$ \\
\hline & & $\begin{array}{l}\text { Radiant Phar. Ltd., Navana Phar. Ltd., Medimet Phar. Ltd., Opsonin Phar. Ltd, Globe } \\
\text { Phar. Ltd., Eskayef (Bd) Ltd., Ziska Phar. Ltd., ACME Laboratories Ltd., Orion Phar. } \\
\text { Ltd., Bio-pharma Laboratories Ltd., Libra Phar. Ltd. } \\
\end{array}$ & $\begin{array}{c}\text { Traxon, Tribac, Triject, Triphin, Trizon, } \\
\text { Vertex, Winner, Xylib }\end{array}$ & $\begin{array}{r}\text { im injections are almost sam } \\
\text { Tk. 20-25। }\end{array}$ & $\begin{array}{l}\text { e. In some cases it is } \\
\text { ess }\end{array}$ & & \\
\hline & Amoxicillin & ( & Moxacil DT & & & & \\
\hline & Dispersible tablet (DT) & square Phar. Ltd. & Moxacil DI & $250 \mathrm{mg} / \mathrm{DT}$ & Tk. 3.50/DT tab. & & \\
\hline & & Opsonin Phar. Ltd, Renata Ltd., Jayson Phar. Ltd., ACI Ltd., Drug International Ltd., & Amoxi, Amoxon, Avlomox, Demoxil, G- & $250 \mathrm{mg} / \mathrm{vial}$ (iv/im) & Tk. 18-22/vial & Yes & Yes \\
\hline & Injection & Gonoshasthya Phar. Ltd., Square Phar. Ltd., Acme Laboratories Ltd., Techno Drugs, & Amoxycillin, Moxaci, Moxilin, Moxin, & $500 \mathrm{mg} / \mathrm{vial}$ (iv/im) & Tk. 21-27/vial & & \\
\hline & & Gaco Phar. Ltd. & Penmox, Unimox & $1000 \mathrm{mg} /$ vial (iv/im) & Tk. 46/vial & & \\
\hline & Drop & $\begin{array}{l}\text { Aexim Phar. Ltd., Ambee Phar. Ltd., Sonear Laboratories Ltd., Syntho Laboratories } \\
\text { Ltd., Pacific Phar. Ltd., Bio Phar. Laboratories Ltd., Doctor's Chemicals Works Ltd., }\end{array}$ & $\begin{array}{l}\text { Almoxil, Ambeexin, Amocap, Amocil, } \\
\text { Amocin, Amotid, Amotid, Amox, Amoxi, }\end{array}$ & $100 \mathrm{mg} / \mathrm{lml}$ & Tk. $27-31 / 15 \mathrm{ml} \mathrm{bot.}$ & & \\
\hline s气 & & Kline (Bd) Ltd, Modern Phar. Ltd., Salton Phar. Ltd., Zenith Phar. Ltd., Jayson Phar. & Amoxima, Amoxipan, Amoxizen, & $125 \mathrm{mg} / 1.25 \mathrm{ml}$ & Tk. $27-31 / 15 \mathrm{ml}$ bot. & & \\
\hline : & Susnoncion $\mathrm{d}$ & $\begin{array}{l}\text { Ltd., Rangs Phar. Ltd., Apollo Phar. Laboratories Ltd., Apex Phar. Ltd, Aristopharma } \\
\text { Ltd., ACI Ltd., Benham Phar. Ltd., Bristol Phar. Ltd., Cosmic Chemical Industries Ltd., }\end{array}$ & $\begin{array}{l}\text { Amoxon, Antif, Apimox, Apoxy, } \\
\text { Aristomox, Avlomox, Bactamox, Benoxil, }\end{array}$ & $125 \mathrm{mg} / 5 \mathrm{ml}$ & $\begin{array}{l}\text { Tk. } 40-55 / 100 \mathrm{ml} \\
\text { bot. }\end{array}$ & & \\
\hline$\frac{\varepsilon}{4}$ & Suspension & $\begin{array}{l}\text { Kumudini Phar. Ltd., Desh Phar. Ltd., Drug International Ltd., Hallmark Phar. Ltd., } \\
\text { Elixir Phar. Ltd., Edruc Ltd., Popular Phar. Ltd., Sanofi-Aventis (Bd) Ltd., GPL, General }\end{array}$ & $\begin{array}{l}\text { Bpmox, Brodamox, Clamox, Demox, } \\
\text { Demoxil, Dopen, Elimox, E-Mox, Fimox, }\end{array}$ & $250 \mathrm{mg} / 5 \mathrm{ml}$ & $\begin{array}{l}\text { Tk. } 60-68 / 100 \mathrm{ml} \\
\text { bot. }\end{array}$ & Yes & Yes $\mathrm{s}^{55}$ \\
\hline & Capsule & $\begin{array}{l}\text { Phar. Ltd., Millat Phar. Ltd., Medimet Phar. Ltd., Hudson Phar. Ltd., Ad-din Phar. Ltd., } \\
\text { Kemiko Phar. Ltd., Asiatic Laboratories Ltd., Belsen Phar. Ltd., Amico Laboratories } \\
\text { Ltd., Central Phar. Ltd., Proteety Phar. Ltd., Decent Phar. Ltd., Square Phar. Ltd., Nipa }\end{array}$ & $\begin{array}{l}\text { Fimoxyl, G-Amoxycillin, Genamox, } \\
\text { Hectamox, Hiconcil, Hi-Mox, J-Mox, } \\
\text { Kamoxy, Loxyl, Moci, Monamox, }\end{array}$ & $250 \mathrm{mg} / \mathrm{cap}$ & Tk. 2.50-3.50/cap & & \\
\hline & & $\begin{array}{l}\text { Phar. Ltd., Marksman Phar. Ltd., Supreme Phar. Ltd., Acme Laboratories Ltd., Opsonin } \\
\text { Phar. Ltd, Shamsul Alamin Phar. Ltd., Mystic Phar. Ltd., Navana Phar. Ltd., Orion }\end{array}$ & $\begin{array}{l}\text { Cemoxin, Mox, Moxa, Moxacil, Moxapen, } \\
\text { Moxatid, Moxico, Moxilin, Moxin ,Mox, }\end{array}$ & $500 \mathrm{mg} / \mathrm{cap}$ & Tk. 4.50-6.50/cap & & \\
\hline & Tablet & $\begin{array}{l}\text { Laboratories Ltd., Peoples Phar. Ltd., Globex Phar. Ltd., APC Phar. Ltd., Techno } \\
\text { Drugs, Pharmadesh Laboratories Ltd., Reman Drug Laboratories Ltd., Rasa Phar. Ltd., }\end{array}$ & $\begin{array}{l}\text { Mumox, Mymoxcil, Navamox, Orixyl, } \\
\text { Pamoxil, Panoxyl, Pemox, Penmox, }\end{array}$ & $250 \mathrm{mg} / \mathrm{tab}$ & Tk. 3.5-4.0/tab & & \\
\hline & & Rephco Laboratories Ltd., Alco Phar. Ltd., Seema Phar. Ltd., Silva Phar. Ltd., Ibn Sina & Pharmoxyl, Remamox, Roxyl, Remoxin, & $875 \mathrm{mg} /$ tablet & Tk. $8.50-10.00 /$ tab & & \\
\hline
\end{tabular}




\begin{tabular}{|c|c|c|c|c|c|c|c|c|}
\hline \multicolumn{3}{|c|}{ Name of commodity } & Name of pharmaceutical companies who manufacture it & Brand names & Available dose? & Market prices? & \begin{tabular}{|c|} 
Separate \\
packaging?
\end{tabular} & $\begin{array}{l}\text { WTP by } \\
\text { end-user? }\end{array}$ \\
\hline \multirow{4}{*}{ 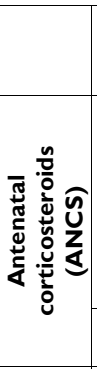 } & & & $\begin{array}{l}\text { Phar. Ind. Ltd., Eskayef (Bd) Ltd., Skylab Ltd., Beximco Phar. Ltd., Somatec Phar. Ltd., } \\
\text { Globe Phar. Ltd., Gaco Phar. Ltd., Ziska Phar. Ltd. }\end{array}$ & $\begin{array}{l}\text { Sapox, Seemaxyl, Simox, Sinamox, Sk-Mox } \\
\text {, Skymoxin, Tycil, Tymox, Ultramox, } \\
\text { Unimox, Zimoxyl }\end{array}$ & & & & \\
\hline & \multirow{2}{*}{\multicolumn{2}{|c|}{ Dexamethasone sodium phosphate }} & Could manufacture by all pharmaceuticals below & (2) & $\begin{array}{l}5 \mathrm{mg} / \mathrm{Iml} \text { amp but } 6 \mathrm{mg} / / 2 \\
\mathrm{mg} / \mathrm{Iml} \text { amp not available }\end{array}$ & - & - & - \\
\hline & & & $\begin{array}{l}\text { Globe Phar. Ltd., Techno Drugs, Opsonin Phar. Ltd, Renata Ltd., Medimet Phar. Ltd., } \\
\text { Rephco Laboratories Ltd., Globe Phar. Ltd., Techno Drugs, Renata Ltd., Medimet } \\
\text { Phar. Ltd., Rephco Laboratories Ltd., Jayson Phar. Ltd., Chemist Laboratories Ltd., Ibn } \\
\text { Sina Phar. Industries Ltd., Ziska Phar. Ltd., Gonoshasthya Phar. Ltd., Gaco Phar. Ltd., } \\
\text { Nuvista Phar. Ltd., Aristopharma Ltd. }\end{array}$ & $\begin{array}{l}\text { D-Cort, Decafos, Decason, Dexa, Dexam, } \\
\text { Dexamet, D-Cort, Decafos, Decason, } \\
\text { Dexa, Dexam, Dexamet, Dexamin, Dexan, } \\
\text { Dexon, Dextason, G-Dexamethasone, } \\
\text { Meradexon, Oradexon, Sonexa }\end{array}$ & $5 \mathrm{mg} / \mathrm{l} \mathrm{ml} \mathrm{amp}$ & Tk. 9-22/amp & No & Yes $^{55}$ \\
\hline & \multicolumn{2}{|c|}{ Betamethasone ${ }^{59}$ sodium phosphate } & Manufacture by a number of pharmaceuticals but different preparation no injection & ( & $\begin{array}{l}\text { Ointment, drop, cream, tablet } \\
\text { (Glaxo) }\end{array}$ & - & No & - \\
\hline \multirow{6}{*}{ 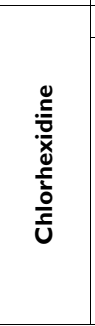 } & \multicolumn{2}{|r|}{ Digluconate } & Not manufacture by any pharmaceuticals & - & $7.1 \%$ aqueous solution & - & No & Yes $^{55}$ \\
\hline & \multirow{5}{*}{ 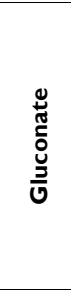 } & Solution & \multirow{5}{*}{$\begin{array}{l}\text { Gonoshasthaya Phar. Ltd, Square Phar. Ltd., Eskayef Bangladesh Ltd., ACI Ltd, } \\
\text { Opsonin Phar. Ltd, Silva Phar. Ltd, Silva Phar. Ltd, Medimet Phar. Ltd., Aristopharma } \\
\text { Ltd. }\end{array}$} & \multirow{5}{*}{$\begin{array}{c}\text { G-Antiseptic, Germisol, Handirub, } \\
\text { Hexiscrub, Hexisol, Kevirub, Safetisol, } \\
\text { Safetisol, Safwash, Xisol, Oralon, Oralon } \\
\text { Dental }\end{array}$} & BP solution & $\begin{array}{l}\text { Tk. }|6-3| / / 00 \mathrm{ml} \\
\text { bot. }\end{array}$ & \multirow{5}{*}{ No } & \multirow{5}{*}{ Yes $^{55}$} \\
\hline & & Hand Rub & & & $\begin{array}{c}\text { Chlorhexidine gluconate } 0.5 \% \\
\mathrm{w} / \mathrm{w} \text { in } 70 \% \text { Isopropanol } \\
\text { solutions }\end{array}$ & $\begin{array}{l}\text { Tk. 24-31/50 ml bot. } \\
\text { Tk. } 80-105 / 250 \mathrm{ml} \\
\text { bot. }\end{array}$ & & \\
\hline & & Hand Rub & & & $\begin{array}{c}\text { Chlorhexidine gluconate } 0.5 \% \\
\text { w/v in Isopropyl alcohol } 20 \% \\
\text { w/v solution }\end{array}$ & \begin{tabular}{|l} 
Tk. $30 / 50 \mathrm{ml}$ bot Tk. \\
$80 / 200 \mathrm{ml}$ bot
\end{tabular} & & \\
\hline & & Solution (Mouth Wash) & & & \begin{tabular}{|c|}
$0.2 \% \mathrm{w} / \mathrm{v}$ solution \\
\end{tabular} & Tk. $35 / 100 \mathrm{ml}$ bot. & & \\
\hline & & Solution & & & $4 \%$ solution & Tk. 100/250 ml bot. & & \\
\hline \multicolumn{3}{|c|}{ Resuscitation devices } & NA & - & $\begin{array}{l}240 \mathrm{ml} / 500 \mathrm{ml} \text { size volume, } \\
\text { specifically designed }\end{array}$ & NA & Not needed & No \\
\hline \multicolumn{3}{|r|}{ ORS $^{60}$} & SMC & ORSaline-N, ORS Fruti, Tasti saline & $\begin{array}{l}\text { Sodium Chloride } 1.30 \mathrm{gm} \text {; } \\
\text { Potassium Chloride } 0.75 \mathrm{gm} \text {; } \\
\text { Tri Sodium Citrate, Dye } \\
\text { Hydrate } 1.45 \mathrm{gm} \text {; Glucose, } \\
\text { Anhydrous } 6.75 \mathrm{gm}^{61}\end{array}$ & Tk. 4.5-6.0/pack & Not needed & Yes $^{55}$ \\
\hline \multirow{3}{*}{\multicolumn{3}{|c|}{$\begin{array}{l}\text { Zinc } 62 \\
\text { Sulphate monohydrate }\end{array}$}} & \multirow{3}{*}{$\begin{array}{l}\text { Acme Laboratories Ltd., Pacific Phar. Ltd., Bristol Phar. Ltd., Benham Phar. Ltd., CPL, } \\
\text { ACl Ltd., Elixir Phar. Ltd., Eskayef Bangladesh Ltd., Edruc Ltd, GPL, Ibn Sina Ltd., Ad- } \\
\text { din Phar. Ltd., Gaco Phar., Renata Ltd, Opsonin Phar. Ltd, NOVO Healthcare and } \\
\text { Phar. Ltd., Aristopharma Ltd., Navana Phar. Ltd., Supreme Phar, Proteety Phar. Ltd., } \\
\text { Orion Phar. Ltd., Nipa Phar. Ltd., Rasa Phar. Ltd., Popular Phar. Ltd., Pharmadesh } \\
\text { Laboratories Ltd., Pharmacia Pvt. Ltd., Jayson Phar. Ltd., Beximco Phar. Ltd., Hudson } \\
\text { Phar. Ltd., Chemist Laboratories Ltd., Cosmic Phar. Pvt Ltd., Alco Phar. Ltd., Square } \\
\text { Phar. Ltd., General Phar. Ltd., Incepta Phar. Ltdd., Globe Phar. Ltd., Zenith Phar. Ltd, } \\
\text { Apollo Phar. Laboratories Ltd., Desh Phar. (Pvt.) Ltdd, Somatec Phar. Ltd., Ziska Phar. } \\
\text { Ltd., Ambee Phar. Ltd., Bikalpa Phar. Ltd., Bio Phar. Laboratories Ltd., Modern Phar. } \\
\text { Ltd., Medicon Laboratories Ltd., Kumudini Phar. Ltd., Rephco Laboratories Ltd., Apex } \\
\text { Phar. Ltd., Acme Laboratories Ltd., Chemico Laboratories Ltd., Marksman Phar. Ltd., } \\
\text { Medimet Phar. Ltd, Drug International Ltd., Unimed \& Unihealth Manufacturers Ltd., } \\
\text { Delta Phar. Ltd, Decent Phar. Laboratories Ltd., Silva Phar. Ltd., Hallmark Phar. Ltd., }\end{array}$} & \multirow{3}{*}{$\begin{array}{l}\text { Baby Zinc, Bimuty, Bimuty, Bp Zinc, B-Zn, } \\
\text { C-Zinc, Dispazinc, E-Zinc, Ezy Xinc, } \\
\text { Grow, G-Zinc, Inate, J-Zinc, Kids-B, Mazic, } \\
\text { Nid, Novo Zinc, Oral-Z, Oralzin, Orazinc, } \\
\text { Pedi-Z, Pem Ds, Pep-2, Peptin, Rozinc, } \\
\text { Soluzinc, Syrup Zinc, Syrup-Zp, Tiny-Z, } \\
\text { Xinc, Z-Dt, Zeal, Zedex, Zee-2, Zeenee, } \\
\text { Zeenk, Zep, Zesup, Zico, Zido, Ziflu, } \\
\text { Zikid, Zimon, Zinca, Zincep, Zincol, } \\
\text { Zincoral, Zinc-S, Zincsy, Zinga, Zinofa, } \\
\text { Zinon, Zinpro, Zinup, Zipol, Zis Ds, } \\
\text { Zismo, Zisul, Zisulmet, Ziton, Zixol, } \\
\text { Znkid, Zs, Z-Sil Dt, Z-Sil, Zym }\end{array}$} & $20 \mathrm{mg} / \mathrm{tab}$ & $\begin{array}{l}\text { Tk. } 1.5-2.0 / 20 \mathrm{mg} \\
\text { tab }\end{array}$ & \multirow{3}{*}{ Not needed } & \multirow{3}{*}{ Yes $^{55}$} \\
\hline & & & & & $10 \mathrm{mg} / 5 \mathrm{ml}$ syrup & $\begin{array}{l}\text { Tk. } 25-30 / 100 \mathrm{ml} \\
\text { bot. }\end{array}$ & & \\
\hline & & & & & $20 \mathrm{mg} / 5 \mathrm{ml}$ syrup & $\begin{array}{l}\text { Tk. } 50-55 / 100 \mathrm{ml} \\
\text { bot. }\end{array}$ & & \\
\hline & & ale condom & Not available & - & - & - & - & - \\
\hline \multirow{2}{*}{\multicolumn{3}{|c|}{$\begin{array}{l}\text { Contraceptive implants } \\
\text { (Implanon/Jadelle) }\end{array}$}} & $\begin{array}{l}\text { Implanon imported from Organon. Marketed by MSD and local distributor is Janata } \\
\text { Traders }\end{array}$ & Implanon & $68 \mathrm{mg}$ etonogestrel/rod & $\$ 8.5$-10/implant & \multirow[t]{2}{*}{ Yes } & \multirow[t]{2}{*}{ No } \\
\hline & & & Jadelle imported from Bayer Schering Phar. AG & (I-plant) & $75 \mathrm{mg}$ levonorgestrel/rod & $\$ 8.0$-10/two stick & & \\
\hline \multicolumn{3}{|c|}{ Emergency contraception } & $\begin{array}{l}\text { Imported from Gedeon Richter (City Overseas), and Renata Ltd., SMC, } \\
\text { Square Phama. Ld. }\end{array}$ & Postinor-2, Emcon, Norix, Norpil I & $\begin{array}{l}0.75 \mathrm{mg} / 1.5 \mathrm{mg} \text { of } \\
\text { Levonorgestrel/tab }\end{array}$ & Tk. 30-45/two tab & Yes & Yes $^{55}$ \\
\hline
\end{tabular}




\section{Appendix 1: Bangladesh Essential Drugs List}

\begin{tabular}{|c|c|c|}
\hline \multicolumn{3}{|c|}{ LIST OF ESSENTIAL DRUGS } \\
\hline Sl. & Name of drugs & Dosage form \\
\hline $\mathrm{I}$ & Abacavir (ABC) & Oral Liquid, Tablet \\
\hline 2 & Acetazolamide & Tablet \\
\hline 3 & Acetylsalicylic acid & Suppository, Tablet \\
\hline 4 & Aciclovir & Powder for injection, Tablet \\
\hline 5 & Albendazole & Tablet (chewable) \\
\hline 6 & Allopurinol & Tablet \\
\hline 7 & Aluminium hydroxide + Magnesium hydroxide & Oral liquid, Tablet \\
\hline 8 & Amitriptyline & Tablet \\
\hline 9 & Amlodipine Besylate & Tablet \\
\hline 10 & Amoxicillin & $\begin{array}{l}\text { Capsule or Tablet, Powder for oral liquid, Powder for } \\
\text { injection }\end{array}$ \\
\hline 11 & Ampicillin & Powder for Injection \\
\hline 12 & Anti-D immunoglobulin (human) & Injection \\
\hline 13 & Antitetanus immunoglobulin (human) & Injection \\
\hline 14 & Artemether + Lumefantrine* & Tablet \\
\hline 15 & Artesunate & Injection, Tablet \\
\hline 16 & Ascorbic Acid & Tablet \\
\hline 17 & Atenolol & Tablet \\
\hline 18 & Atropine & Injection, Solution (eye drops) \\
\hline 19 & Barium Sulfate & Aqueous suspension \\
\hline 20 & BCG vaccine & Injection \\
\hline 21 & Benzathine benzylpenicillin & Powder for injection \\
\hline 22 & Benzoic acid + Salicylic acid & Ointment or cream \\
\hline 23 & Benzyl benzoate & Lotion \\
\hline 24 & Benzyl penicillin & Powder for injection \\
\hline 25 & Betamethasone & Ointment or cream \\
\hline 26 & Bleomycin & Powder for injection \\
\hline 27 & Bupivacaine & Injection \\
\hline 28 & Calcium gluconate & Injection \\
\hline 29 & Carbamazepine & Oral liquid, Tablet (chewable), Tablet (scored) \\
\hline 30 & Charcoal, activated & Powder \\
\hline 31 & Chlorambucil & Tablet \\
\hline 32 & Chloramphenicol & Eye drops, Eye ointment \\
\hline 33 & Chlorhexidine & Solution \\
\hline 34 & Chloroquine & Oral liquid, Tablet \\
\hline 35 & Chlorpheniramine & Injection, Tablet \\
\hline 36 & Chlorpromazine & Injection, Oral liquid, Tablet \\
\hline 37 & Ciprofloxacin & Tablet or powder for suspension \\
\hline 38 & Cisplatin & Injection \\
\hline 39 & Clofazimine & Capsule \\
\hline 40 & Clotrimazole & Vaginal cream, Vaginal tablet \\
\hline 41 & Cloxacillin & Capsule, Powder for injection, Power for oral liquid, \\
\hline 42 & Condoms & \\
\hline 43 & Cyclophosphamide & Powder for injection, Tablet \\
\hline 44 & Dapsone & Tablet \\
\hline 45 & Dexamethasone & Injection \\
\hline 46 & Dextran 70 & Injectable solution \\
\hline 47 & Diazepam & Injection, Tablet, Tablet (scored) \\
\hline 48 & Didanosine (ddl) & $\begin{array}{l}\text { Buffered powder for oral liquid, Capsule (unbuffered enteric } \\
\text { coated), Tablet (buffered chewable, dispersible) }\end{array}$ \\
\hline 49 & Diethylcarbamazine & Tablet \\
\hline 50 & Digoxin & Injection, Oral liquid, Tablet \\
\hline 51 & Diloxanide & Tablet \\
\hline 52 & Diphtheria antitoxin & Injection \\
\hline 53 & Diptheria vaccine & Injection \\
\hline 54 & Dopamine & Injection \\
\hline
\end{tabular}




\begin{tabular}{|c|c|c|}
\hline 55 & Doxorubicin & Powder for injection \\
\hline 56 & Doxycycline & Capsule or Tablet, Tablet (dispersible) \\
\hline 57 & DPT vaccine & Oral + Injection \\
\hline 58 & Efavirenz (EFV or EFZ) & Capsule, Oral liquid, Tablet \\
\hline 59 & Enalapril & Tablet \\
\hline 60 & Epinephrine (adrenaline) & Injection, Solution (eye drops) \\
\hline 61 & Ergocalciferol & Capsule or Tablet, Oral liquid \\
\hline 62 & Ergometrine & Injection \\
\hline 63 & Erythromycin & $\begin{array}{l}\text { Capsule or Tablet, Powder for injection, Powder for oral } \\
\text { liquid }\end{array}$ \\
\hline 64 & Ethambutol & Tablet \\
\hline 65 & Ethinylestradiol + Levonorgestrel & Tablet \\
\hline 66 & Ferrous salt & Oral liquid, Tablet \\
\hline 67 & Ferrous salt + Folic acid & Capsule, Tablet \\
\hline 68 & Fluconazole & Capsule, Oral liquid \\
\hline 69 & Fluorescein & Eye drops \\
\hline 70 & Fluorouracil & Injection, Ointment \\
\hline 71 & Fluphenazine & Injection \\
\hline 72 & Folic acid & Tablet \\
\hline 73 & Furosemide & Injection, Tablet \\
\hline 74 & Gentamycin & Injection, Solution (eye drops) \\
\hline 75 & Gentamycin + Hydrocortisone & Ear drop \\
\hline 76 & Glibenclamide & Tablet \\
\hline 77 & Gliclazide & Tablet \\
\hline 78 & Glucose & Injectable solution \\
\hline 79 & Glucose with sodium chloride & Injectable solution \\
\hline 80 & Glyceryl trinitrate & Tablet (sublingual) \\
\hline 81 & Griseofulvin & Capsule or Tablet \\
\hline 82 & Haloperidol & Injection, Tablet \\
\hline 83 & Halothane & Inhalation \\
\hline 84 & Heparin sodium & Injection \\
\hline 85 & Hepatitis B vaccine & Injection \\
\hline 86 & Homatropine & Solution (eye drops) \\
\hline 87 & Human normal immunoglobulin & Intramuscular administration, Intravenous administration \\
\hline 88 & Hydrochlorothiazide & Tablet (scored) \\
\hline 89 & Hydrocortisone & Powder for injection, Ointment or cream, Suppository \\
\hline 90 & Hyoscine butylbromide & Tablet, Injection \\
\hline 91 & Ibuprofen & Tablet \\
\hline 92 & Indinavir (IDV) & Capsule \\
\hline 93 & Insulin Injection (Soluble) & Injection \\
\hline 94 & Isoniazide & Tablet, Tablet (scored) \\
\hline 95 & Isoniazide + Ethambutol & Tablet \\
\hline 96 & Isosorbide dinitrate & Tablet (sublingual) \\
\hline 97 & Ketamine & Injection \\
\hline 98 & Lamivudine (3TC) & Oral liquid, Tablet, \\
\hline 99 & Levamisole & Tablet \\
\hline 100 & Levodopa + Carbidopa & Tablet \\
\hline 101 & Levothyroxine & Tablet \\
\hline 102 & Lidocaine & Injection, Topical \\
\hline 103 & Lithium Carbonate & Capsule or tablet \\
\hline 104 & Lopinavir + Ritonavir (LPV/r) & Capsule, Oral liquid \\
\hline 105 & Magnesium hydroxide & Oral liquid \\
\hline 106 & Magnesium sulfate* & Injection \\
\hline 107 & Mannitol & Injectable solution \\
\hline 108 & Measles vaccine & Injection \\
\hline 109 & Mebendazole & Tablet (chewable) \\
\hline 110 & Mefloquine & Tablet \\
\hline 111 & Metformin & Tablet \\
\hline 112 & Methotrexate & Powder for injection, Tablet \\
\hline
\end{tabular}




\begin{tabular}{|c|c|c|}
\hline 113 & Methyldopa & Tablet : $250 \mathrm{mg}$ \\
\hline 114 & Methylrosanilinium chloride (gentian violet) & Aqueous solution, Tincture \\
\hline 115 & Metoclopramide & Injection, Tablet \\
\hline 116 & Metronidazole & Injection, Oral liquid, Suppository, Tablet \\
\hline 117 & Miconazole & Ointment/Ceam \\
\hline 118 & Miltefosine & Capsule/Oral liquid \\
\hline 119 & Misoprostol & Tablet \\
\hline 120 & Morphine & Injection, Oral liquid, Tablet, Tablet (prolonged release) \\
\hline 121 & Naloxone & Injection \\
\hline 122 & Nelfinavir (NFV) & Oral powder, Tablet \\
\hline 123 & Neomycin Sulfate + Bacitracin & Ointment \\
\hline 124 & Neostigmine & Injection, Tablet \\
\hline 125 & Nevirapine (NVP) & Oral liquid, Tablet \\
\hline 126 & Nicotinamide & Tablet \\
\hline 127 & Nifedipine & Immediate release capsule \\
\hline 128 & Nitrofurantoin & Tablet \\
\hline 129 & Nitrous oxide & Inhalation \\
\hline 130 & Nystatin & Oral Suspension \\
\hline$|3|$ & Omeprazole & Capsule \\
\hline 132 & Oral rehydration salts & Powder \\
\hline 133 & Oseltamivir & Tablet \\
\hline 134 & Oxygen & Inhalation \\
\hline 135 & Oxytocin & Injection \\
\hline 136 & Paracetamol & Oral liquid, Suppository, Tablet \\
\hline 137 & Paromomycin & Solution for intramuscular injection \\
\hline 138 & Peritoneal Dialysis Solution & Intraperitoneal dialysis solution (of appropriate composition) \\
\hline 139 & Permethrin & Cream, Lotion \\
\hline 140 & Pertussis vaccine & Injection \\
\hline $14 \mid$ & Pethidine hydrochloride & Injection \\
\hline 142 & Phenobarbital & Injection, Oral liquid, Tablet \\
\hline 143 & Phenoxymethylpenicillin & Powder for oral liquid, Tablet, \\
\hline 144 & Phenytoin & Capsule, Injection, Oral liquid, Tablet, Tablet (chewable) \\
\hline 145 & Pilocarpine & Solution (eye drops) \\
\hline 146 & Poliomyelitis vaccine & Oral \\
\hline 147 & Polyvalent anti snake venom & Injection \\
\hline 148 & Potassium chloride & Tablet, Solution \\
\hline 149 & Povidone lodine & Solution \\
\hline 150 & Prednisolone & Tablet, Solution (eye drops) \\
\hline 151 & Primaquine & Tablet \\
\hline 152 & Procainamide & Injection \\
\hline 153 & Procaine benzylpenicllin & Powder for injection \\
\hline 154 & Procarbazine & Capsule \\
\hline 155 & Proguanil & Tablet \\
\hline 156 & Promethazine & Oral liquid, Injection, Oral liquid, Tablet \\
\hline 157 & Propranolol & Tablet \\
\hline 158 & Protamine sulfate & Injection \\
\hline 159 & Pyrazinamide & Tablet, Tablet (dispersible), Tablet (scored) \\
\hline 160 & Pyridoxine & Tablet \\
\hline 161 & Pyrimethamine & Tablet \\
\hline 162 & Quinine & Injection, Tablet \\
\hline 163 & Rabies immunoglobulin & Injection \\
\hline 164 & Rabies vaccine & Injection \\
\hline 165 & Retinol & Capsule, Tablet, Oral oily solution, Water-miscible injection \\
\hline 166 & Riboflavin & Tablet \\
\hline 167 & Rifampicin & Capsule or Tablet \\
\hline 168 & Rifampicin + Isoniazid & Tablet \\
\hline 169 & Rifampicin + Isoniazid + Ethambutol & Tablet \\
\hline
\end{tabular}




\begin{tabular}{|c|c|c|}
\hline 170 & Rifampicin + Isoniazid + Pyrazinamide & Tablet \\
\hline I7I & Rifampicin + Isoniazid + Pyrazinamide + Ethambutol & Tablet \\
\hline 172 & Ritonavir & Oral liquid, Oral solid dosage form \\
\hline 173 & Salbutamol & $\begin{array}{l}\text { Injection, Oral liquid, Respirator solution for use in nebulizers, } \\
\text { Tablet }\end{array}$ \\
\hline 174 & Salicylic acid & Solution \\
\hline 175 & Saquinavir (SQV) & Capsule \\
\hline 176 & Senna & Tablet \\
\hline 177 & Silver sulfadiazine & Cream \\
\hline 178 & Sodium chloride & Injectable solution \\
\hline 179 & Sodium Chloride 3\% & $\mathrm{I} / \mathrm{V}$ fluid \\
\hline 180 & $\begin{array}{l}\text { Sodium Chloride quartet strength }(0.225 \%)+ \\
\text { Dextrose } 5 \%\end{array}$ & I/V fluid \\
\hline 181 & Sodium Hydrogen Carbonate & Injectable solution, Soution \\
\hline 182 & Sodium stibogluconate & Injection \\
\hline 183 & Sodium thiosulfate & Solution \\
\hline 184 & Spironolactone & Tablet \\
\hline 185 & Stavudine (d4t) & Capsule, Powder for oral liquid \\
\hline 186 & Streptomycin & Powder for injection \\
\hline 187 & Sulfadoxine + Pyrimethamine & Tablet \\
\hline 188 & Sulfamethoxazole + Trimethoprim & Oral liquid, Tablet, Injection \\
\hline 189 & Suxamethonium & Injection, Powder for injection \\
\hline 190 & Tamoxifen & Tablet \\
\hline 191 & Tenofovir disoproxil fumarate (TDF) & Tablet \\
\hline 192 & Tetanus vaccine & Injection \\
\hline 193 & Tetracycline & Eye ointment \\
\hline 194 & Thiamine & Tablet \\
\hline 195 & Thiopental & Powder for injection \\
\hline 196 & Trimethoprim & Tablet \\
\hline 197 & Tropicamide & Eye drops \\
\hline 198 & Tuberculin, purified protein derivative (PPD) & Injection \\
\hline 199 & Valproic acid & Oral liquid, Tablet (crushable), Tablet (enteric coated) \\
\hline 200 & Vecuronium & Injection \\
\hline 201 & Verapamil & Injection, Tablet \\
\hline 202 & Vinblastine & Powder for injection \\
\hline 203 & Vincristine & Powder for injection \\
\hline 204 & $\begin{array}{l}\text { Vitamin B-Complex (Vitamin B - } 5 \text { mg + Vitamin B2- } \\
2 \mathrm{mg}+\text { Vitamin B6 - } 2 \mathrm{mg}+\text { Nicotinamide } 20 \mathrm{mg} \text { ) }\end{array}$ & Tablet \\
\hline 205 & Warfarin & Tablet \\
\hline 206 & Water for Injection & Ampoule \\
\hline 207 & Xylometazoline Hydrochloride & Nasal drops \\
\hline 208 & Zidovudine (ZDV or AZT) & Capsule, Oral liquid, Solution for IV infusion injection, Tablet \\
\hline 209 & Zinc sulphate & Oral liquid, Tablet \\
\hline
\end{tabular}

N.B: Shaded items are the drugs in the 13 life-saving commodities 


\section{Appendix 2: Contents of Drug and Dietary Supply (DDS) Kits}

\section{DDS Kit Contents}

Annex.. XIII..

\begin{tabular}{|c|c|c|c|}
\hline $\mathrm{S} ! \#$ & Product Name & $\begin{array}{l}\text { INN/Generic Name \& } \\
\text { Strength }\end{array}$ & Piesent Quantity in DDS Kits \\
\hline 1 & 2 & 3 & 4 \\
\hline 1. & $\begin{array}{l}\text { Tab.Iron \& Folic } \\
\text { Acid }\end{array}$ & $\begin{array}{l}\text { Ferrous Fumarate }(200 \mathrm{mg}) \\
+ \text { Folic Acid }(0.20 \mathrm{mg}) \\
\text { BP/USP }\end{array}$ & $\begin{array}{l}2000 \text { tabs } \\
\text { (1000 :abs in one Plastic Container) } \\
-02 \text { Packet. }\end{array}$ \\
\hline 2. & $\begin{array}{l}\text { Tab. Vitamin } \\
\text { B Complex }\end{array}$ & $\begin{array}{l}\text { Vitamin B Complex } \\
\text { (Thiamine } \mathrm{HCl}-5 \mathrm{mg} \text {. } \\
\text { Pyridoxine } \mathrm{HCl}-2 \mathrm{mg} \text {. } \\
\text { Riboflavin-2 mg \& } \\
\text { Nicotinamide-20 mg) } \\
\text { BP/USP }\end{array}$ & $\begin{array}{l}1000 \text { tibs } \\
\text { (10 tats per bilster/strip) } \\
50 \text { blis:ers/Strips in one packet } \\
-02 \text { Pasket. }\end{array}$ \\
\hline 3. & Tab Albendazole & $\begin{array}{l}\text { Albendazole }(400 \mathrm{mg} / \mathrm{Tab} .) \\
\text { BP/USP }\end{array}$ & $\begin{array}{l}200 \text { tats } \\
\text { ( } 1 \text { tab fer blister/strip). } \\
50 \text { blist: } 2 \text { rs/strips in one packet } \\
-04 \text { Packet. }\end{array}$ \\
\hline 4. & Tab. Paracetamol & $\begin{array}{l}\text { Paracetamol }(500 \mathrm{mg} / \mathrm{Tab} .) \\
\text { BP/USP }\end{array}$ & $\begin{array}{l}1000 \text { tajs } \\
\text { (10 tabs per blister/strip). } \\
50 \text { blisters/Strips in one packet } \\
-02 \text { Packet. }\end{array}$ \\
\hline 5. & Tab. Antacid & $\begin{array}{l}\text { Dried Al. Hydroxide gel } \\
(250 \text { mg })^{+} \\
\text {Mg. Hydroxide }(400 \mathrm{mg}) \\
\text { BPlUSP }\end{array}$ & $\begin{array}{l}500 \text { tab: } \\
\text { (10 tabs per blister/strip) } \\
25 \text { blisters/strips in one packet } \\
-02 \text { Pacl:et. }\end{array}$ \\
\hline 6. & $\begin{array}{l}\text { Tab.Drotaverine } \\
\text { Hydrocloride }\end{array}$ & $\begin{array}{l}\text { Drotaverine Hydrocloride } \\
\text { (40mg/tab)INN }\end{array}$ & $\begin{array}{l}100 \text { tabs } \\
\text { (10 tabs per blister/strip) } \\
10 \text { bliste s/strips in one packet. }\end{array}$ \\
\hline 7. & $\begin{array}{l}\text { Tab. Ranitidine } \\
\text { Hydrocioride }\end{array}$ & $\begin{array}{l}\text { Ranitidine Hydrocloride } \\
\text { (150 mg) } \\
\text { BP/USP }\end{array}$ & $\begin{array}{l}300 \text { tabs } \\
\text { (10 tabs ser blister/strip) } \\
10 \text { blisters/strips in, one packet } \\
-03 \text { Packet. }\end{array}$ \\
\hline 8. & Tab. Motronidazole & $\begin{array}{l}\text { Metronidazole }(400 \mathrm{mg} / \mathrm{tab}) \\
\text { BPIUSP }\end{array}$ & $\begin{array}{l}500 \text { tabs } \\
\text { (10 tabs !er blister) } \\
50 \text { blister; in one packes. }\end{array}$ \\
\hline 9. & $\begin{array}{l}\text { Tab. } \\
\text { Chiorpheniramine } \\
\text { Maleate }\end{array}$ & $\begin{array}{l}\text { Chlorpheniramine Maleate } \\
\text { (4 mg/tab) BP/USP }\end{array}$ & $\begin{array}{l}200 \text { tabs } \\
(10 \text { tabs } \xi \text { er blister) } \\
20 \text { blisters in one packet }\end{array}$ \\
\hline 10. & Tab. Salbutamol & $\begin{array}{l}\text { Salbutamol Sulphate } \\
\text { (4 mg/tab) BPfUSP }\end{array}$ & $\begin{array}{l}100 \text { tabs } \\
\text { (10 tabs fer blister/strip) } \\
10 \text { blisters/strips in } 01 \text { packet. }\end{array}$ \\
\hline 11. & Tab. Ibuprufen & $\begin{array}{l}\text { Ibuprufen }(400 \mathrm{mg}\rangle \\
\text { BPIUSP }\end{array}$ & $\begin{array}{l}100 \text { tabs } \\
\text { (10 tabs per blister/strip) } \\
10 \text { blisters'strips in one packet. }\end{array}$ \\
\hline 12. & Tab. Diazepam & $\begin{array}{l}\text { Diazepam (5 mg/tab) } \\
\text { BP/USP }\end{array}$ & $\begin{array}{l}50 \text { tabs. } \\
\text { (10 tabs per blister/strip) } \\
5 \text { blisters/ itrips in one rubber band. }\end{array}$ \\
\hline 13. & $\begin{array}{l}\text { Tab Cotrimoxazole } \\
120 \mathrm{mg} \text { (dispersible) }\end{array}$ & $\begin{array}{l}\text { Sulfamethoxazole } \\
\text { (100 mg)+ } \\
\text { Trimethoprim ( } 20 \mathrm{mg}) \\
\text { BPfUSP }\end{array}$ & $\begin{array}{l}300 \text { tabs } \\
\text { (10 tabs per blister/strip) } \\
30 \text { blisters/strips in one packet. }\end{array}$ \\
\hline 14. & $\begin{array}{l}\text { Tab. Cotrimoxazole } \\
\text { (480 mg) }\end{array}$ & $\begin{array}{l}\text { Sulfamethoxazole } \\
\text { (400 mg)+ } \\
\text { Trimethoprim ( } 80 \mathrm{mg} \text { ) } \\
\text { BPIUSP }\end{array}$ & $\begin{array}{l}500 \text { tabs } \\
\text { (10 tabs per blister/strip) } \\
50 \text { blisters/.jtrips in one packet. }\end{array}$ \\
\hline 15. & Cap. Amoxycillin & $\begin{array}{l}\text { Amoxycillin Trihydrate } \\
\text { (250 mg/Cap) } \\
\text { BP/USP }\end{array}$ & $\begin{array}{l}500 \text { tabs } \\
\text { (10 tabs pe: blister/strip) } \\
50 \text { blister/s rip in one packet. }\end{array}$ \\
\hline
\end{tabular}


Population Council Dhaka, Bangladesh 